DR. JAMES JOHNSON (Orcid ID : 0000-0002-9008-111X)

PROF. STEFANO CARNICELLI (Orcid ID : 0000-0001-5431-2569)

MR. ARNE VERSTRAETEN (Orcid ID : 0000-0002-8813-1261)

Article type : Primary Research Articles

\title{
The response of soil solution chemistry in European forests to
}

\section{decreasing acid deposition}

James Johnson $^{1}$

Elisabeth Graf Pannatier ${ }^{2}$

Stefano Carnicelli ${ }^{3}$

Guia Cecchini ${ }^{3}$

Nicholas Clarke ${ }^{4}$

Nathalie Cools ${ }^{5}$

Karin Hansen ${ }^{6 a, b}$

Henning Meesenburg ${ }^{7}$

Tiina M. Nieminen ${ }^{8}$

Gunilla Pihl -Karlsson ${ }^{9}$

Hugues Titeux ${ }^{10}$

This article has been accepted for publication and undergone full peer review but has not been through the copyediting, typesetting, pagination and proofreading process, which may lead to differences between this version and the Version of Record. Please cite this article as doi: $10.1111 / \mathrm{gcb} .14156$

This article is protected by copyright. All rights reserved. 
Elena Vanguelova ${ }^{11}$

Arne Verstraeten ${ }^{5}$

Lars Vesterdal ${ }^{12}$

Peter Waldner ${ }^{2}$

Mathieu Jonard ${ }^{10}$

${ }^{1}$ School of Agriculture and Food Science, University College Dublin, Belfield, Dublin 4, Ireland

${ }^{2}$ WSL, Swiss Federal Institute for Forest, Snow and Landscape Research, Zürcherstrasse 111, CH8903 Birmensdorf, Switzerland

${ }^{3}$ Earth Sciences Department, University of Florence, Via La Pira 4, 50125 Firenze, Italy

${ }^{4}$ Norwegian Institute of Bioeconomy Research, P.O. Box 115, N-1431 Ås, Norway

${ }^{5}$ Research Institute for Nature and Forest (INBO), Havenlaan 88, 1000 Brussels, Belgium

${ }^{6 a}$ IVL Swedish Environmental Research Institute, Box 210 60, SE-100 31 Stockholm, Sweden

${ }^{6 \mathrm{~b}}$ Swedish Environmental Protection Agency, SE-106 48 Stockholm, Sweden

${ }^{7}$ Northwest German Forest Research Institute, Grätzelstrasse 2, D-37079 Göttingen, Germany

${ }^{8}$ Natural Resources Institute Finland Luke, Latokartanonkaari 9, 00790 Helsinki, Finland

${ }^{9 a}$ IVL Swedish Environmental Research Institute, Box 530 21, SE-400 14 Göteborg, Sweden ${ }^{10}$ UCLELI, Université Catholique de Louvain, Earth and Life Institute, Croix du Sud 2, L7.05.09, BE-1348 Louvain-la-Neuve, Belgium

${ }^{11}$ Centre for Ecosystem, Society and Biosecurity, Forest Research, Farnham, Surrey, GU10 4LH, UK

${ }^{12}$ Department of Geosciences and Natural Resource Management, University of Copenhagen, Rolighedsvej 23, DK-1958 Frederiksberg C, Denmark

This article is protected by copyright. All rights reserved. 
Keywords: soil acidification, air pollution, acid deposition, aluminium, sulphur, nitrogen, DOC, critical loads

Running head: Trends in soil solution in European forests

Corresponding author: James Johnson, tel: 35386 1614924, email jim.johnson@ucd.ie

\section{Abstract}

Acid deposition arising from sulphur $(\mathrm{S})$ and nitrogen $(\mathrm{N})$ emissions from fossil fuel combustion and agriculture has contributed to the acidification of terrestrial ecosystems in many regions globally. However, in Europe and North America, S deposition has greatly decreased in recent decades due to emissions controls. In this study we assessed the response of soil solution chemistry in mineral horizons of European forests to these changes. Trends in $\mathrm{pH}$, acid neutralising capacity (ANC), major ions, total aluminium $\left(\mathrm{Al}_{\text {tot }}\right)$, and dissolved organic carbon (DOC) were determined for the period 1995-2012. Plots with at least 10 years of observations from the ICP Forests monitoring network were used. Trends were assessed for the upper mineral soil $(10-20 \mathrm{~cm}, 104$ plots $)$ and subsoil $(40-80 \mathrm{~cm}$, 162 plots). There was a large decrease in the concentration of sulphate $\left(\mathrm{SO}_{4}^{2-}\right)$ in soil solution; over a ten-year period (2000-2010), $\mathrm{SO}_{4}^{2-}$ decreased by $52 \%$ at $10-20 \mathrm{~cm}$ and $40 \%$ at $40-80 \mathrm{~cm}$. Nitrate was unchanged at $10-20 \mathrm{~cm}$ but decreased at $40-80 \mathrm{~cm}$. The decrease in acid anions was accompanied by a large and significant decrease in the concentration of the nutrient base cations, calcium, magnesium and potassium $\left(\mathrm{Bc}=\mathrm{Ca}^{2+}+\mathrm{Mg}^{2+}+\mathrm{K}^{+}\right)$and $\mathrm{Al}_{\text {tot }}$ over the entire dataset. The response of soil solution acidity was non-uniform. At 10-20 cm, ANC increased in acid-sensitive soils (base saturation $\leq 10 \%$ ) indicating a recovery, but ANC decreased in soils with base saturation $>10 \%$. At $40-80 \mathrm{~cm}$ ANC remained unchanged in acid-sensitive soils (base saturation $\leq 20 \%, \mathrm{pH}_{\mathrm{CaCl}_{2}} \leq 4.5$ ) and decreased 
in better-buffered soils (base saturation $>20 \%, \mathrm{pH}_{\mathrm{CaCl}_{2}}>4.5$ ). In addition, the molar ratio of $\mathrm{Bc}$ to $\mathrm{Al}_{\text {tot }}$ either did not change or decreased. The results suggest a long-time lag between emission abatement and changes in soil solution acidity and underline the importance of long-term monitoring in evaluating ecosystem response to decreases in deposition.

\section{Introduction}

Air pollution can impact forest health directly, through foliar damage, and indirectly, through soilmediated effects on nutrient availability and root functioning which in turn can exacerbate natural stress factors such as drought and pest outbreaks (De Vries et al., 2000). Acid deposition arising from emissions of sulphur (S) and nitrogen (N) from fossil fuel combustion and agriculture has contributed to the acidification of terrestrial ecosystems in many regions globally (Bouwman et al., 2002). Acid deposition increases the concentration of protons $\left(\mathrm{H}^{+}\right)$and strong acid anions (AA), including sulphate $\left(\mathrm{SO}_{4}^{2-}\right)$, nitrate $\left(\mathrm{NO}_{3}^{-}\right)$and chloride $\left(\mathrm{Cl}^{-}\right)$, in soils, which increases the rate of base cation leaching $\left(\mathrm{Ca}^{2+}, \mathrm{Mg}^{2+}, \mathrm{K}^{+}, \mathrm{Na}^{+}\right)$and associated soil acidification. In forest soils, acid deposition is primarily buffered by Bc released from mineral weathering (Ulrich, 1983). However, when the rate of proton deposition exceeds $\mathrm{Bc}$ weathering, soil solution becomes more acidic, with a decrease in $\mathrm{pH}$ and acid neutralizing capacity $(\mathrm{ANC})$ - the difference between $\mathrm{Bc}$ and $\mathrm{AA}\left(\mathrm{ANC}=\left(\mathrm{Ca}^{2+}+\mathrm{Mg}^{2+}+\right.\right.$ $\left.\left.\mathrm{K}^{+}+\mathrm{Na}^{+}\right)-\left(\mathrm{SO}_{4}^{2-}+\mathrm{NO}_{3}^{-}+\mathrm{Cl}^{-}\right)\right)$. This in turn can bring potentially toxic forms of aluminium (Al) and other metals into solution (Reuss and Johnson, 1986). In addition, soil exchangeable Bc pools are depleted and base saturation (BSat) the proportion of $\mathrm{Bc}$ on the soil cation exchange complex, decreases. As a result, in poorly buffered soils (BSat<20\%), acid deposition results in elevated inorganic $\mathrm{Al}$ and $\mathrm{H}^{+}$in soil solution and drainage waters (Driscoll et al., 2001).

This article is protected by copyright. All rights reserved. 
Ecological impacts on forests have been widely documented. Acid deposition has resulted in a decline of sugar maple and red spruce stands in eastern North America due to soil $\mathrm{Ca}^{2+}$ depletion (DeHayes et al., 1999; Sullivan et al., 2013; Battles et al., 2014). In Europe, high levels of Al in soil solution have reduced $\mathrm{Mg}^{2+}$ nutrition in Norway spruce (de Wit et al., 2010; Lomský et al., 2012). High inorganic $\mathrm{Al}$ in soil solution can also impact tree fine root growth and functioning (Godbold et al., 2003; Vanguelova et al., 2007a). Acid deposition also significantly altered carbon (C) and N cycling in soil organic horizons of Norway spruce forests in the Czech Republic (Oulehle et al., 2011). In China, acid deposition has resulted in significant acidification of subtropical forest soils (Liu et al., 2010; Larssen et al., 2011; Liu et al., 2011; Zhu et al., 2016).

In recent decades, air pollution reduction policies, such as the Convention on Long-Range Transboundary Air Pollution (CLRTAP) (UNECE, 1979) in Europe and the Clean Air Act Amendments in North America have resulted in large decreases in S emissions. Nitrogen emissions also decreased but not to the same extent (EEA, 2016). As a result, there has been a large decrease in atmospheric $\mathrm{S}$ deposition. In Europe, precipitation $\mathrm{SO}_{4}^{2-}$ decreased by $73 \%$ between $1990-2012$ (Colette et al., 2016). Meanwhile, $\mathrm{NO}_{3}^{-}$in precipitation decreased by $33 \%$ for the same period (Colette et al., 2016). In many parts of the world however, acid deposition is increasing due to rapid economic expansion (Dentener et al., 2006) such that many forests will experience acid deposition in the future (Posch et al., 2015). For example, in industrialized and agriculturally intensive areas of China, rates of inorganic $\mathrm{N}$ deposition are like peak levels in northwestern Europe in the 1980s (Liu et al., 2013). Evaluating responses to changes in acid deposition is thus key to supporting worldwide effective emissions controls and recovery of impacted ecosystems.

There has been much focus on the response of sensitive soils and surface waters in Europe and North America to acid deposition. In surface waters, there has been an almost universal decrease in $\mathrm{SO}_{4}^{2-}$ often accompanied by increasing pH and ANC (Stoddard et al., 1999; Skjelkvåle et al., 2007; Garmo 
et al., 2014; Driscoll et al., 2016). The response varies regionally with delayed recovery of $\mathrm{pH}$ and ANC in some areas (Strock et al., 2014) due to desorption of $\mathrm{SO}_{4}^{2-}$ accumulated in soils and depletion of soil Bc pools (Alewell et al., 2000a; Futter et al., 2014; Fakhraei et al., 2016; Watmough et al., 2016).

Monitoring of the effects of air pollution on forest health has been carried out in Europe by ICP Forests (International Co-operative Programme on Assessment and Monitoring of Air Pollution Effects on Forests) under the CLRTAP. Soil solution has been monitored at the intensive monitoring Level II plots in the ICP Forests network since the early 1990s (De Vries et al., 2003). The chemistry of soil solution provides an indication of nutrient availability, potential acid stress to fine roots and mycorrhizae (Binkley and Fisher, 2012) as well as potential exceedance of deposition critical loads. The molar ratio of nutrient cations $\left(\mathrm{Bc}=\mathrm{Ca}^{2+}+\mathrm{Mg}^{2+}+\mathrm{K}^{+}\right)$, to total aluminium, $\mathrm{Bc}: \mathrm{Al}_{\text {tot }}$ or the $\mathrm{Ca}^{2+}$ to $\mathrm{Al}_{\text {tot }}$ ratio $\left(\mathrm{Ca}: \mathrm{Al}_{\text {tot }}\right)$ are often used as indicators of toxic effects of $\mathrm{Al}$ on plant roots (Cronan et al., 1989; Sverdrup and Warfvinge, 1993). They are also used as the chemical criteria in calculating critical loads of acidity in forests; a Bc: $\mathrm{Al}_{\text {tot }}$ threshold of between 0.6 and 1.2 is applied depending on tree species (CLRTAP, 2017).

In contrast to surface waters, there have been relatively few regional assessments of changes in soil solution in response to decreasing acid deposition. Iost et al. (2012) found no change in the soil solution $\mathrm{Bc}: \mathrm{Al}_{\text {tot }}$ molar ratio or inorganic $\mathrm{N}$ at ICP Forests plots with at least 5 years of data up to the mid-2000s. However, changes in S, pH, ANC and other parameters have yet to be assessed.

The soil solution data collected at intensively monitored plots in the ICP Forests network represent a unique long-term dataset to assess the response of soil solution acidity to decreasing $\mathrm{SO}_{4}^{2-}$ and inorganic $\mathrm{N}$ deposition in recent decades. The data have been collected using harmonised methods for sampling and analysis, making it possible to assess changes at the European scale. Specific objectives 
were to characterise the chemistry of soil solution with respect to acidity ( $\mathrm{pH}, \mathrm{ANC}, \mathrm{Bc}$ : $\mathrm{Al}_{\text {tot }}$ ), major ions and dissolved organic carbon (DOC) and to assess the temporal changes in these parameters since the mid-1990s. It was expected that the decrease in $\mathrm{SO}_{4}^{2-}$ and inorganic $\mathrm{N}$ deposition would result in less $\mathrm{SO}_{4}^{2-}$ and $\mathrm{NO}_{3}^{-}$in soil solution. This in turn was expected to result in an increase in $\mathrm{ANC}, \mathrm{Bc}: \mathrm{Al}_{\mathrm{tot}}$ and $\mathrm{pH}$ in poorly buffered soils and a decrease in soil solution $\mathrm{Bc}$ in better-buffered soils. As such, trends were stratified by soil buffering capacity. Soil solution chemistry also varies biogeographically (Garmo et al., 2014), between forest types (Kristensen et al., 2004) and by the magnitude of atmospheric deposition. A second objective was to assess the influence of these factors on soil solution trends.

\section{Materials and methods}

\section{Sample collection and analysis}

Soil solution, throughfall deposition and soil chemistry data from the ICP Forests Level II monitoring network were used (Lorenz, 2010). Deposition data were processed by the ICP Forests Expert Panel on Deposition as described by Waldner et al. (2014). Throughfall and soil solution data used for the 42 Swedish plots were collected within the SWETHRO network (Pihl Karlsson et al., 2011). Soil $\mathrm{pH}_{\mathrm{CaCl}_{2}}$ and BSat, from a soil survey in the mid 1990s, were provided by the Forest Soil Coordinating Centre (FSCC) of ICP Forests. Methods for soil solution collection, analysis and quality control have been harmonized since 1995 and are described in the ICP Forests manual on soil solution collection and analysis (Nieminen et al., 2016). The number of lysimeters varied among plots and depth intervals and was generally reported as a single value either from analysis of a pooled sample or the average of individual samples. A mandatory minimum of three lysimeters per depth interval was required (Nieminen et al., 2016). Sampling took place weekly, fortnightly or monthly. After sample collection, a subsample was taken for determination of $\mathrm{pH}$ and conductivity. The remaining sample was passed through a $0.45 \mu \mathrm{m}$ membrane filter and analysed for major ions $\left(\mathrm{Ca}^{2+}, \mathrm{Mg}^{2+}, \mathrm{K}^{+}, \mathrm{Na}^{+}\right.$, 
$\mathrm{NH}_{4}^{+}, \mathrm{SO}_{4}^{2-}, \mathrm{NO}_{3}^{-}, \mathrm{Cl}^{-}$), DOC and $\mathrm{Al}_{\text {tot }}$. Laboratories in ICP Forests network participating countries carried out the analyses. Sample collection and analysis were subject to quality assurance and quality control checks including the use of control charts for internal reference, charge balance and participation in laboratory ring tests (König et al., 2013; Marchetto et al., 2009). Sampling below canopy throughfall and of open field bulk precipitation was carried out at the plots, and on a nearby opening, respectively, following the ICP Forests manual on sampling and analysis of deposition (Clarke et al., 2016). In general, between 3 and 20 replicate collectors were used and samples collected at weekly, fortnightly or monthly intervals.

\section{Time series selection}

Temporal changes were tested for plots that had at least 10 years of data between 1995 and 2012. Time series with gaps of 5 years or more were excluded. Soil solution was sampled using a range of lysimeters; the most common was the tension (suction-cup) lysimeter. To avoid artifacts due to sampler type, the analysis was applied for tension lysimeters only. In addition, data from organic soils (Histosols) were excluded, as they would be expected to respond differently than mineral soils to changes in deposition. Sampling depths ranged from just below the forest floor $(0 \mathrm{~cm})$ down to $4 \mathrm{~m}$, with $90 \%$ of the lysimeters located between 0 and $80 \mathrm{~cm}$. In general, lysimeters were installed in the upper mineral soil corresponding to the rooting zone and at a deeper depth, considered to be below the rooting zone. The time series were grouped into two depth intervals: upper mineral soil: $10-20 \mathrm{~cm}$ representing the upper, more organic rich rooting zone and lower mineral soil: $40-80 \mathrm{~cm}$ representing a deeper, more mineral horizon where water was draining from the soil profile. Where more than one depth was sampled in an interval, the depth closest to the median of all the plots was selected; either $20 \mathrm{~cm}$ (for $10-20 \mathrm{~cm}$ interval) or $50 \mathrm{~cm}(40-80 \mathrm{~cm}$ interval).

This article is protected by copyright. All rights reserved. 


\section{Site and soil description}

A total of 171 plots were included. Of these, 104 had soil solution data at $10-20 \mathrm{~cm}, 162$ at $40-80 \mathrm{~cm}$ (Fig. 1) and 95 at both depth intervals. Of the 171 plots, 120 were primarily coniferous stands and 51 were dominated by deciduous trees. The most common tree species were Picea abies (L.) Karst. (67), Pinus sylvestris L. (35) and Fagus sylvatica L. (31). Median soil $\mathrm{pH}_{\mathrm{CaCl}_{2}}$ was 3.9 in the $10-20 \mathrm{~cm}$ depth interval and 4.4 at $40-80 \mathrm{~cm}$ (Table 1). The number of plots with $\mathrm{pH}_{\mathrm{CaCl}_{2}}<5$ was 93 (of 100) in the upper depth interval and 124 (of 145) in the lower depth interval. The majority were acid soils and buffered via silicate weathering, cation exchange and, at lower $\mathrm{pH}$, the dissolution of aluminium oxides and hydroxides (Ulrich, 1983). Base saturation was low, median values being $11 \%$ and 20\% in the two depth intervals, respectively. A BSat of $20 \%$ was observed as a threshold at which acid deposition resulted in the mobilisation of $\mathrm{Al}$ and $\mathrm{H}^{+}$to surface waters (Driscoll et al., 2001). The ranges of soil $\mathrm{pH}_{\mathrm{CaCl}_{2}}$ and $\mathrm{BSat}$ were representative of those reported from the ICP Forests Level I network (Cools and de Vos, 2011).

\section{Data pre-treatment}

Values reported as below quantification limit were replaced either by a value submitted by individual countries to represent the quantification limit over the time (10 countries), or by the limit of detection values submitted to the ICP Forests database in 2010 (3 countries). Secondly, the precision of data (number of decimal places) submitted to the database changed over the study period. Levene's test (Levene, 1960) was used to test for homogeneity of variance in the data at different levels of precision and there were no significant differences so that trend analysis could be applied across the whole-time series. At some plots, data from individual lysimeters were reported in the database, in which case the median value was used. Soil solution data were aggregated to monthly time intervals by taking the median of multiple observations per month, where present. Trends in $\mathrm{pH}$, major ions $\left(\mathrm{Ca}^{2+}, \mathrm{Mg}^{2+}\right.$,

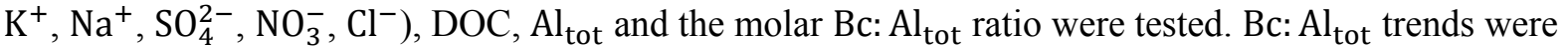


also tested for soils with $\mathrm{pH}_{\mathrm{CaCl} 2}<5.0$, where the ratio is closer to the critical limit. In addition, trends were tested for AA, Bc and ANC. Ammonium in soil solution was close to or below detection limit for most plots and was not analysed for trends. The normality of soil solution data was evaluated for skewness and kurtosis (Pearson's kurtosis, R) using the 'moments' package in R. Except for $\mathrm{pH}$ and ANC, the data were heavily skewed. Hence, a log-transformation was applied to improve normality for all the other parameters $\left(\mathrm{Ca}^{2+}, \mathrm{Mg}^{2+}, \mathrm{K}^{+}, \mathrm{Na}^{+}, \mathrm{SO}_{4}^{2-}, \mathrm{NO}_{3}^{-}, \mathrm{Cl}^{-}, \mathrm{DOC}, \mathrm{Al}_{\text {tot }}, \mathrm{AA}, \mathrm{Bc}, \mathrm{Bc}^{\mathrm{Al}} \mathrm{Al}_{\text {tot }}\right)$. Deposition consisted of monthly fluxes of throughfall and open field bulk precipitation. Details of data preparation and checks are described in Waldner et al. (2014).

\section{Trends at the European scale}

A linear mixed-effects model was used to detect temporal changes in soil solution at the European scale, like that applied by Jonard et al. (2015). The intercept and slope of the model contained both fixed and random effects. For the intercept, the fixed parameter 'a' corresponded to solute concentration in the year 2000 and 'month' to the monthly intercept (Eqn. 1). As the intercept of the linear model would correspond to the concentration in the year 0 , the data were centred on the year 2000 by subtracting 2000 from the sampling year. Another random factor $c$ try $y_{\text {int }}$ was used to account for country effects (e.g. due to differences in sample collection or analysis among countries) and a random factor plot $_{\text {int }}$ was used to account for plot effects. Another random factor $\left(\right.$ year $_{\text {int }}$ ) was included to account for the non-linear interannual variability.

For the slope, parameter $\mathrm{b}$ is the fixed part describing the slope over time- - the long-term change. Random coefficients $\left(c t r y_{s l p}\right)$ and plots $\left(\right.$ plot $\left._{s l p}\right)$ were included to account for individual country and plot changes (Eqn. 1).

This article is protected by copyright. All rights reserved. 
solute var. $=\left[\mathrm{a}+\right.$ month $\left.+\operatorname{ctry}_{\mathrm{int}}\left(0, \sigma_{\mathrm{ci}}^{2}\right)+\operatorname{plot}_{\mathrm{int}}\left(0, \sigma_{\mathrm{pi}}^{2}\right)+\operatorname{year}_{\mathrm{int}}\left(0, \sigma_{\mathrm{yi}}^{2}\right)\right]$

$$
+\left[\mathrm{b}+\operatorname{ctry}_{\mathrm{slp}}\left(0, \sigma_{\mathrm{cs}}^{2}\right)+\operatorname{plot}_{\mathrm{slp}}\left(0, \sigma_{\mathrm{ps}}^{2}\right)\right] \cdot(\text { year }-2000)+\varepsilon\left(0, \sigma^{2}\right)
$$

where $\sigma_{\mathrm{ci}}^{2}$ is the variance of the intercept (i) due to random factor country, $\sigma_{\mathrm{pi}}^{2}$ the variance of the intercept (i) due to plot factor and $\sigma_{\mathrm{yi}}^{2}$ the intercept variance due to random factor year. $\sigma_{\mathrm{cs}}^{2}$ is the variance of the slope (s) due to random factor country and $\sigma_{\mathrm{ps}}^{2}$ random slope variance due to plot effects.

Several covariance structures were tested to test if accounting for serial autocorrelation would improve the model. The structures tested were autoregressive (AR), Toeplitz, autoregressive moving average (ARMA) and three forms of spatial covariance (exponential, linear and power). The tests were carried out on a subset of data and evaluated by comparing the information criteria (AIC, BIC) of the fitted model. The best fit was given by the autoregressive moving average (ARMA), which then was used in the full dataset.

For log-transformed data, the fitted values of the fixed parameters were used to report the change relative to the intercept over 10 years according to:

$$
\text { relative } 10 \text { year change }(\%)=\frac{10^{a+5 \cdot b}-10^{a-5 \cdot b}}{10^{a}} \cdot 100
$$

For untransformed data the relative change was described by:

$$
\text { relative } 10 \text { year change }(\%)=\frac{b \cdot 10}{a} \cdot 100
$$

The fitting of the linear model was carried out with the MIXED procedure of the SAS software (version 9.3; SAS institute Inc., Cary, NC, USA). 


\section{Trends at individual plots}

The linear mixed-effects model was run at individual plots with 'year' and 'month' as fixed factors and 'year' as a random factor. At each plot, the intercept in the year 2000 gave the concentration for that year. These values were used to calculate summary statistics for soil solution in the year 2000 . The linear model was run for throughfall chemical changes at individual plots and the relative change was calculated as above. The plots were then assigned to two categories of throughfall and included in the analysis by environmental factors.

\section{Stratification by environmental factors}

To assess the influence of environmental factors on soil solution trends, additional models were run with these factors included as fixed factors. The models tested whether temporal trends differed among levels of the factor. Factors were limited to two or three levels to avoid fragmenting the data into too many small subsets of plots making the detection of trends difficult. The variables were region, forest type, soil acidity, and trends in throughfall deposition.

The factor region was included to reflect regional changes in deposition, as well as biogeography and climatic influences on soil acidity trends. Countries were assigned to three regions as follows: North (Norway, Sweden, Finland), West (Belgium, Denmark, France, Ireland, United Kingdom) and Central (Austria, Germany, Switzerland). Plots in Spain (1) and Italy (2) were not included as there were not enough to form a category for southern Europe.

Soil solution trends could differ between deciduous and coniferous plots due to differences in nutrient cycling, deposition magnitude and trends as well as soil fertility. For example, it has been shown that there was a greater response in soil solution $\mathrm{NO}_{3}^{-}$to atmospheric inputs at broadleaf forests in Europe, as they are usually located on more fertile soils (Kristensen et al., 2004).

This article is protected by copyright. All rights reserved. 
Soil acidity is an important determinant of soil solution chemistry and would be expected to moderate the response to deposition changes. In more acidic soils, decreased acid input should result in less inorganic $\mathrm{Al}$ and $\mathrm{H}^{+}$in soil solution, whereas $\mathrm{Bc}$ response should be more evident in less acidic soils. We divided the plots into two categories of soil $\mathrm{pH}_{\mathrm{CaCl}_{2}}$ and BSat using their median values. The values differed with depth interval, as the upper layer was more acidic.

For $\mathrm{SO}_{4}{ }^{2-}$, throughfall provides an indication of the total deposition (Clarke et al., 2016). Plots were divided into groups based on the change in flux for a ten-year period relative to the year 2000. For throughfall $\mathrm{SO}_{4}^{2-}$, the plots were divided into two categories based on the median, e.g. for $\mathrm{SO}_{4}^{2-}$ the median trend was a $60 \%$ decrease over ten years, so plots were grouped into those with a greater decrease and those with a smaller (Table 2). Soil solution trends were tested between levels of throughfall $\mathrm{Bc}$, inorganic $\mathrm{N}\left(\mathrm{NO}_{3}^{-}+\mathrm{NH}_{4}^{+}\right)$and potential acidity $\left(\mathrm{Ac}_{\text {pot }}\right)$, which was used to account for the potential acidifying effect due to nitrification of $\mathrm{NH}_{4}^{+}$deposition. Potential acidity is the sum of total deposition of non-marine AA plus $+\mathrm{NH}_{4}^{+}$minus non-marine $\mathrm{Bc}\left(\mathrm{Ac}_{\mathrm{pot}}=\mathrm{nmSO}_{4}^{2-}+\right.$ $\left.\mathrm{nmCl}^{-}+\mathrm{NO}_{3}^{-}+\mathrm{NH}_{4}^{+}-\mathrm{nmBCnmBCc}\right)(\mathrm{CLRTAP}, 2017)$. The non-marine fraction was calculated assuming all $\mathrm{Na}^{+}$was of marine origin and then using the ratio of $\mathrm{Na}^{+}$to other ions in seawater to calculate their marine and non-marine fractions.

\section{Results}

\section{Soil solution statistics}

Soil solution was acidic at most plots with median ANC values of -47 and $-26 \mu \mathrm{eq} \mathrm{L}^{-1}$ in the year 2000, at 10-20 cm and 40-80 cm depth respectively (Table 3, Fig. 2, Fig. 3). Soil solution pH was lower at $10-20 \mathrm{~cm}$ than at $40-80 \mathrm{~cm} ; 5^{\text {th }}$ and $95^{\text {th }}$ percentiles were 3.7 and 7.0 at $10-20 \mathrm{~cm}$, and 4.1 and 7.7 at $40-80 \mathrm{~cm}$ (Table 3). At $10-20 \mathrm{~cm}, \mathrm{Ca}^{2+}$ made the greatest contribution to $\mathrm{Bc}$, followed by $\mathrm{Na}^{+}, \mathrm{Mg}^{2+}$ and $\mathrm{K}^{+}$. At $40-80 \mathrm{~cm}, \mathrm{Na}^{+}$was the most abundant $\mathrm{Bc}$ followed by $\mathrm{Ca}^{2+}, \mathrm{Mg}^{2+}$ and $\mathrm{K}^{+}$. 
The difference between depths was likely due to the inclusion of 42 plots from Sweden at $40-80 \mathrm{~cm}$. These plots had a higher $\mathrm{Na}^{+}$concentration due to marine deposition. Median $\mathrm{Bc}$ : $\mathrm{Al}_{\text {tot }}$ ratio was 1.4 and 1.5 in both depth intervals, respectively. The concentration of DOC decreased with depth, with median values of $12 \mathrm{mg} \mathrm{L}^{-1}$ at 10-20 $\mathrm{cm}$ and $6.8 \mathrm{mg} \mathrm{L}^{-1}$ at 40-80 $\mathrm{cm}$ (Table 3, Fig. 2, Fig. 3).

Sulphate was the anion in highest concentration in soil solution, and it increased markedly from shallow to deeper soil depths (Table 3). Chloride concentrations were also relatively high; median values were 94 and $106 \mu$ eq $\mathrm{L}^{-1}$ at $10-20 \mathrm{~cm}$ and $40-80 \mathrm{~cm}$. Median $\mathrm{NO}_{3}^{-}$was 16 and $7.2 \mu \mathrm{eq} \mathrm{L}^{-1}$ (0.23 and $\left.0.10 \mathrm{mg} \mathrm{N} \mathrm{L}^{-1}\right)$ at $10-20 \mathrm{~cm}$ and $40-80 \mathrm{~cm}$, respectively. However, there were considerable regional differences in $\mathrm{NO}_{3}^{-}$with some areas having concentrations close to detection limit, while others had elevated $\mathrm{NO}_{3}^{-}$. At $10-20 \mathrm{~cm}, 46$ plots (44\%) had median concentrations greater than $1 \mathrm{mg}$ $\mathrm{N} \mathrm{L}^{-1}\left(71 \mu \mathrm{eq} \mathrm{L} \mathrm{L}^{-1}\right.$ ), a proposed threshold for critical $\mathrm{N}$ leaching and saturation (Gundersen et al., 2006; Stoddard, 1994). At 40-80 cm, the number of plots with median higher than $1 \mathrm{mg} \mathrm{N} \mathrm{L}^{-1}$ was 51 $(31 \%)$.

\section{Trends in soil solution: global model}

There was a large and significant decrease in the concentrations of $\mathrm{SO}_{4}^{2-}, \mathrm{Bc}$ and $\mathrm{Al}_{\text {tot }}$ at both soil depths over the monitoring period (Table 4, Fig. 2, Fig. 3). Sulphate decreased by $52 \%$ and $40 \%$ at 10-20 $\mathrm{cm}$ and 40-80 $\mathrm{cm}$ respectively over a ten-year period, a change in concentration of -61 and -69 $\mu e q \mathrm{~L}^{-1}$, respectively. Concentrations of $\mathrm{Ca}^{2+}$ decreased by -57 and $-68 \mu \mathrm{eq} \mathrm{L}^{-1}$ over a ten-year period, while $\mathrm{Mg}^{2+}$ decreased by -24 and $-18 \mu \mathrm{eq} \mathrm{L}^{-1}$ and $\mathrm{K}^{+}$by -7.1 and $-3.5 \mu \mathrm{eq} \mathrm{L}^{-1}$ at the two depths (Table 4). Nitrate was unchanged at 10-20 $\mathrm{cm}$ but showed a relative decrease of $30 \%$ at $40-80$ $\mathrm{cm}$. There was no change in $\mathrm{Na}^{+}$or $\mathrm{Cl}^{-}$. Overall, $\mathrm{Bc}$ decreased by $47 \%$ and $26 \%$ over a ten-year period. These decreases offset the decrease in AA such that ANC did not change (Table 4, Fig. 2, Fig. 3). In addition, there were no significant trends in soil solution $\mathrm{pH}$. Total $\mathrm{Al}$ declined at both depths; relative decreases were $19 \%$ at $10-20 \mathrm{~cm}$ and $17 \%$ at $40-80 \mathrm{~cm}$ over ten years. Despite the decrease in 
$\mathrm{Al}_{\text {tot }}$, the $\mathrm{Bc}$ : $\mathrm{Al}_{\text {tot }}$ ratio of acidic soils $\left(\mathrm{pH}_{\mathrm{CaCl}_{2}}<5.0\right)$ showed no change. The concentration of DOC showed a small but significant decrease (17\%) at $40-80 \mathrm{~cm}$ but no change at $10-20 \mathrm{~cm}$ (Table 4 , Fig.

2, Fig. 3).

With the exceptions of DOC and $\mathrm{NO}_{3}^{-}$, trends were similar between soil depths (Table 4). The significance, direction and magnitude were similar when the analysis was carried out on the forest plots common to both soil depths (Supporting Information; Table S1). The only differences were for $\mathrm{NO}_{3}^{-}$, which no longer was significant at $40-80 \mathrm{~cm}$, and $\mathrm{Na}^{+}$, which showed a small but significant decrease at $10-20 \mathrm{~cm}$.

There were also similarities between trends in soil solution and deposition. Significant decreasing trends were found for $\mathrm{SO}_{4}^{2-}$, inorganic $\mathrm{N}$ and $\mathrm{Bc}$ in throughfall at the plots (Supporting Information; Table S2). Throughfall $\mathrm{SO}_{4}^{2-}$ decreased by $60 \%$ over a ten-year period, a change in concentration of $-35 \mu$ eq $\mathrm{L}^{-1}$ (Table S2). Throughfall inorganic $\mathrm{N}$ decreased by $33 \%$ over ten years relative to 2000 and by a concentration of $-17 \mu \mathrm{eq} \mathrm{L}^{-1}$. Trends were significant for both $\mathrm{NO}_{3}^{-}$and $\mathrm{NH}_{4}^{+}$in throughfall deposition. Base cation deposition in throughfall also decreased but not to the same extent as AA. The relative ten-year change in $\mathrm{Bc}$ was $-14 \%$. As a result, $\mathrm{ANC}$ increased in throughfall, by $+27 \mu \mathrm{eq} \mathrm{L}^{-1}$ over ten years. ANC was unchanged in bulk precipitation, which suggests that dry deposition of S and/or internal cycling of $\mathrm{Bc}$ influenced ANC in throughfall. $\mathrm{pH}$ increased significantly in both bulk precipitation and throughfall (Supporting Information; Table S2). The difference in ANC and $\mathrm{pH}$ trends in bulk precipitation was likely due to a difference in the datasets used, ANC was not available at all plots, while other plots were missing $\mathrm{pH}$ in some years.

This article is protected by copyright. All rights reserved. 


\section{Trends in soil solution, stratified by environmental factors}

There was a non-uniform response of soil solution acidity when stratified by soil buffering capacity. At 40-80 cm, decreases in deposition resulted in greater changes in soil solution concentrations of $\mathrm{Bc}$ in better-buffered soils $\left(\mathrm{pH}_{\mathrm{CaCl}_{2}}>4.5, \mathrm{BSat}>20 \%\right)$. This was due to the larger decrease in $\mathrm{Ca}^{2+}$ in soil solution in these soils as might be expected due to their buffering capacity (Table 5). However, the decrease in AA did not match that of Bc and ANC decreased in these soils as a result (Table 5). In contrast, in soils with $\mathrm{pH}_{\mathrm{CaCl}_{2}} \leq 4.5$, there was a greater decrease in $\mathrm{SO}_{4}^{2-}$ and $\mathrm{NO}_{3}^{-}$, but there was no trend in ANC in these soils. Aluminium decreased significantly in both groups, but more in the more acidic one $\left(\mathrm{pH}_{\mathrm{CaCl}_{2}} \leq 4.5, \mathrm{BSat} \leq 20 \%\right)$. When sites were classified according to BSat, the trends were similar; soils with BSat $>20 \%$ experienced greater decrease in Bc and decreasing ANC trend compared to those with BSat $\leq 20 \%$ (Supporting Information; Table S3). As such, at 40-80 cm, soil solution acidity was unchanged in the more acidic soil group but continued to increase in betterbuffered soils.

At 10-20 cm there was no difference in trends between soils classified by soil $\mathrm{pH}_{\mathrm{CaCl}_{2}}$ (Table 5); however, soils with BSat $\leq 10 \%$ showed a significant increase in ANC, whereas those with BSat $>10 \%$ had significantly decreasing ANC (Supporting Information; Table S3).

Forest type (coniferous/deciduous) had a significant influence on soil solution Bc trends. At both soil depths, $\mathrm{Ca}^{2+}$ decreased more under deciduous plots while $\mathrm{K}^{+}$decreased more under coniferous plots (Table 5). Magnesium, $\mathrm{Na}^{+}$and $\mathrm{Bc}$ decreased significantly more in deciduous plots at $40-80 \mathrm{~cm}$. The relative change in these ions was generally higher in coniferous plots where concentrations were lower. At 40-80 cm, there was a significant increase in ANC at coniferous plots and a decrease at deciduous plots. At $10-20 \mathrm{~cm}, \mathrm{Al}_{\text {tot }}$ decreased significantly at coniferous plots. The trends for forest type were somewhat like those for soil $\mathrm{pH}$ and BSat. This was due to covariance between factors; coniferous plots had lower BSat and greater decreases in throughfall $\mathrm{SO}_{4}^{2-}$ than deciduous plots (Supporting Information; Table S4).

This article is protected by copyright. All rights reserved. 
There were few regional differences in soil solution trends (Table 5). At 10-20 cm, the only difference was for $\mathrm{Mg}^{2+}$, which decreased more in the Central region compared to the North and West Europe. At $40-80 \mathrm{~cm}, \mathrm{Al}_{\text {tot }}$ decreased more in the Central and West regions than in northern Europe and a significant decrease in DOC was evident in the Central and Western regions but not in the North (Table 5).

There were few differences in soil solution trends when plots were grouped by changes in throughfall $\mathrm{SO}_{4}^{2-}, \mathrm{Ac}_{\text {pot }}, \mathrm{Bc}$ or inorganic $\mathrm{N}$. At $10-20 \mathrm{~cm}, \mathrm{SO}_{4}^{2-}$ showed a response to throughfall; soil solution $\mathrm{SO}_{4}^{2-}$ decreased more at plots with larger decreases in throughfall $\mathrm{SO}_{4}^{2-}$ (Table 5). In contrast, at 40$80 \mathrm{~cm}, \mathrm{Al}_{\text {tot }}$ decreased more in plots where throughfall $\mathrm{SO}_{4}^{2-}$ decreased by less than $60 \%$ but $\mathrm{ANC}$ declined significantly at these plots. Overall, there were few significant trends, or few consistent trends between depth intervals or among throughfall $\mathrm{SO}_{4}^{2-}, \mathrm{Ac}_{\text {pot }}, \mathrm{Bc}$ or inorganic $\mathrm{N}$ categories (Supporting Information; Table S3).

\section{Discussion}

\section{Large decrease in soil solution $\mathrm{SO}_{4}^{2-}$}

The large decrease in deposition and soil solution $\mathrm{SO}_{4}^{2-}$ at the European scale was similar to observations from individual forest plots (Brumme et al., 2009; Vanguelova et al., 2010; Pihl Karlsson et al., 2011; Verstraeten et al., 2012; Waldner et al., 2014) and surface waters (Prechtel et al., 2001; Kvaalen et al., 2002; Garmo et al., 2014; Driscoll et al., 2016) and consistent with the large decrease in $\mathrm{SO}_{2}$ emissions in Europe and North America (EEA, 2016). Trends in soil solution $\mathrm{SO}_{4}^{2-}$ at $10-20 \mathrm{~cm}$ were similar in magnitude to changes in throughfall. Larger changes were observed at plots with larger decreases in throughfall $\mathrm{SO}_{4}^{2-}$, suggesting that the upper soil layer responded rapidly to changes in inputs. However, the 
magnitude of the soil solution decrease at 40-80 cm was lower than at 10-20 cm. Many studies have reported a lag in response of $\mathrm{SO}_{4}^{2-}$ in soil solution and surface waters to decreasing $\mathrm{SO}_{4}^{2-}$ deposition (Oulehle et al., 2006; Meesenburg et al., 2016). This has been attributed to desorption of previously deposited $\mathrm{SO}_{4}{ }^{2-}$ from soils (Sokolova and Alekseeva, 2008; Fakhraei et al., 2016), dissolution of Al-hydroxy-sulphates (Khanna et al., 1987) or climate induced changes in S cycling (Mitchell and Likens, 2011). Release of $\mathrm{SO}_{4}^{2-}$ from soils is generally higher in areas with historically high deposition (Oulehle et al., 2006), and $\mathrm{SO}_{4}^{2-}$ desorption isotherms suggest it can take decades for soil solution to reach a steady state with current inputs (Alewell et al., 2000a).

\section{Decreasing Bc in soil solution}

The strong temporal decline in soil solution $\mathrm{SO}_{4}^{2-}$ (and overall AA) was partly balanced by a significant decrease in $\mathrm{Bc}$. The comparable magnitudes of $\mathrm{AA}$ and $\mathrm{Bc}$ trends suggest that the changes in strong acid anions drove trends in $\mathrm{Bc}$ and as such, that $\mathrm{Bc}$ weathering and release were the primary buffering mechanism for acid deposition. Throughfall $\mathrm{Ca}^{2+}$ and $\mathrm{Mg}^{+}$also decreased significantly and likely contributed to decreasing Bc in soil solution. Where soil exchangeable $\mathrm{Bc}$ pools and weathering rates were small, $\mathrm{Bc}$ deposition can influence soil solution cations (Watmough et al., 2005). Several studies have pointed to Bc deposition as a factor in temporal soil solution changes (Alewell et al., 2000a; Fölster et al., 2003; Vanguelova et al., 2010; Ukonmaanaho et al., 2014). Tree uptake of Bc is an important flux, but it is unlikely to have caused the large decrease in soil solution. Although forest growth has increased in Europe (Ciais et al., 2008), the rate of Bc uptake has not kept pace.

Observations of foliar $\mathrm{Bc}$ nutrition at Level II plots indicate that there has been a progressive deterioration of the foliar $\mathrm{Bc}$ nutrition of European beech and common oak, while no overall 
change in foliar Bc nutrition has been observed for conifer plots (Jonard et al., 2015).

Conversely, it is not evident that changes in soil solution $\mathrm{Bc}$ and $\mathrm{Al}_{\text {tot }}$ have influenced foliar nutrition in European forests. The changes observed in foliar Bc of broadleaved plots were rather due to a dilution effect associated with an increased growth rate (Jonard et al., 2015). In addition, in the ICP Forests network, most plots have normal foliar Bc levels. Berger et al. (2016) similarly found adequate Bc nutrition in beech stands in Austria and declining foliar Bc trends despite increasing soil exchangeable cations.

\section{Trends in soil solution $\mathrm{pH}$ and $\mathrm{ANC}$}

The results indicate a non-uniform response to decreases in acid deposition. In the upper soil, poorly buffered soils (BSat $<10 \%$ ) showed a significant increase in ANC as expected. However, at $40-80 \mathrm{~cm}$, ANC decreased in better-buffered soils (BSat $>20 \%$ ), which was not expected. In some respects, these trends reflect those reported by individual studies. At some sites soil solution $\mathrm{pH}$ and ANC increased (Vanguelova et al., 2010; Johnson et al., 2013; Fuss et al., 2015); however, in others acidity remained unchanged or aggravated (Graf Pannatier et al., 2011; Verstraeten et al., 2012; Meesenburg et al., 2016). Trends in acidity appear to be spatially variable, and dependent on factors including soil conditions, forest type, deposition levels and climate. For example, in Sweden, sites in the south, which historically received the highest deposition, showed a recovery in $\mathrm{pH}, \mathrm{ANC}$ and inorganic $\mathrm{Al}$, while sites in other parts of the country did not (Pihl-Karlsson et al., 2011). In the UK, trends of acidity $(\mathrm{pH}, \mathrm{ANC})$ were variable among 10 plots, with the greatest response occurring at sandy soil sites with the largest deposition reductions (Vanguelova et al., 2010). When aggregated at the European scale, it could be that opposing trends cancel each other out, as was the likely case here.

This article is protected by copyright. All rights reserved. 
ANC decreased in better-buffered soils at $40-80 \mathrm{~cm}$ because $\mathrm{SO}_{4}^{2-}$ and $\mathrm{NO}_{3}^{-}$did not decrease as much as Bc. Ongoing acidification has been attributed to release of previously adsorbed S (Meesenburg et al., 2016; Oulehle et al., 2006) as well as decreasing Bc deposition (Ukonmaanaho et al., 2014; Verstraeten et al., 2012; Fölster et al., 2003; Alewell et al., 2000a) mentioned above. In addition, forests in parts of Europe (Switzerland, Denmark, Belgium, Germany) are characterised by high N deposition and $\mathrm{NO}_{3}^{-}$in soil solution, which contributes to soil acidification (Hansen et al., 2007; Graf Pannatier et al., 2011; Verstraeten et al., 2012; Waldner et al., 2014). The response has also been hampered by mobilisation of acid cations $\left(\mathrm{H}^{+}, \mathrm{Al}\right)$ due to marine ion deposition in Atlantic coastal areas, which could have influenced the trends (Akselsson et al., 2013; Löfgren et al., 2011). Another source of noise in the data arises from the nature of the suction cup lysimeters. In these samples, it is not possible to determine how long the sample has had to equilibrate with the soil, which could vary among collection periods making the detection of trends more difficult.

The differing acidification trends reflect the results of some repeat soil surveys. In a comparison of soil $\mathrm{pH}$ and BSat between two soil surveys 12 years apart, Cools and De Vos (2011) found a recovery of BSat in more acidic soils $\left(\mathrm{pH}_{\mathrm{CaCl}_{2}}<4.0\right.$, BSat $\left.<20 \%\right)$ but a decrease in less acidic soils $\left(\mathrm{pH}_{\mathrm{CaCl}_{2}}>\right.$ 4.0, BSat $>20 \%$ ). Lawrence et al. (2015) reported an initial recovery in the $\mathrm{O}$ horizon at sites in northeastern US and eastern Canada, but BSat continued to decline in the B-horizon at a third of the same sites. This suggests that the rate of $\mathrm{S}$ and inorganic $\mathrm{N}$ deposition might still exceed buffering capacity in these soils and/or that the lag between deposition reductions and soil response is longer than expected.

For deeper soils, ANC showed no change in poorly buffered soils. Recovery in these soils could be limited by decreases in soil solution $\mathrm{Bc}$ due to historic depletion of soil exchangeable Bc pools (Houle et al., 2006; Warby et al., 2005; van der Heijden et al., 2011). At one of the best-documented sites of soil acidification, at Solling in Germany, soil exchangeable Bc pools were depleted by as much as 
60\% (Meesenburg et al., 2016). Weathering rates were low in these soils, and exchangeable pools could take decades to recover (Reinds et al., 2009). Repeated soil surveys over 50 years in Germany indicate that the rates of $\mathrm{Bc}$ and $\mathrm{BSat}$ loss from mineral soils have levelled off at many forest plots, with some showing an increase in BSat (Wellbrock et al., 2016). Overall, the decrease in soil solution $\mathrm{Bc}$ concentration indicates that the rate of $\mathrm{Bc}$ depletion has slowed. Soil exchangeable pools could recover if the rates of $\mathrm{Bc}$ weathering were sufficient to balance the $\mathrm{Bc}$ loss. Further research should focus on the magnitude and direction of $\mathrm{Bc}$ budgets at the plots to determine the potential for recovery in poorly buffered soils.

\section{Trends in soil solution $\mathbf{A l}_{\text {tot }}$}

Aluminium decreased in soil solution across the whole dataset and at $40-80 \mathrm{~cm}$ it decreased more in acidic soils. This was expected given that $\mathrm{Al}$ dissolution is a buffering mechanism in acidic soils. However, the $\mathrm{Bc}: \mathrm{Al}_{\text {tot }}$ ratio did not increase in these soils. There are more reasons for this. Data for $\mathrm{Al}_{\text {tot }}$ were used, which includes both the inorganic and organic $\mathrm{Al}$ fractions (Fakhraei et al., 2015), of which the organic can be significant (Brumme et al., 2009). For example, in Norway, Lange et al. (2006) found that the proportion of organically bound $\mathrm{Al}$ in soil solution was $39 \%$ and $26 \%$ at 15 and $40 \mathrm{~cm}$, respectively, while in the UK, Vanguelova et al. (2007b) found the proportion to be $30-40 \%$ in podzols. There were no changes in DOC at $10-20 \mathrm{~cm}$ and a relative decrease of $17 \%$ for a ten-year period at $40-80$ $\mathrm{cm}$. The small changes in DOC would have maintained the organic fraction of $\mathrm{Al}$ in solution, potentially dampening the trends. However, organically bound $\mathrm{Al}$ is less toxic to biota and a shift in favour of this fraction could support the recovery of drainage waters.

This article is protected by copyright. All rights reserved. 
A second point relates to ionic strength of soil solution and cation exchange. Matschonat and Vogt (1998) found that a decrease in cation concentration resulted in the preferential adsorption of trivalent cations on the soil exchange complex relative to di- and mono-valent cations. It would thus be expected that there would be more of a decrease in Al relative to other cations, and an increase in ANC. However, this was not the case. A possible explanation is that the dissolution and precipitation of $\mathrm{Al}$ oxides and hydroxides are strongly $\mathrm{pH}$ dependent (Reuss and Johnson, 1986) and, as the $\mathrm{pH}$ of soil solution did not change, ionic forms of Al remained soluble.

\section{No change in DOC in the upper mineral soil}

DOC showed no change $(10-20 \mathrm{~cm})$ or decreased $(40-80 \mathrm{~cm})$ in soil solution. National studies show non-uniform results; some forest plots previously impacted by acid deposition show increasing DOC concentrations (Hruška et al., 2009; Verstraeten et al., 2014), whereas no changes are evident in others (Ukonmaanaho et al., 2014). In addition, surface horizons often show increasing DOC while mineral horizons show no changes, or decreases (Borken et al., 2011; Sawicka et al., 2016). The results at 10-20 cm are like those observed by Camino-Serrano et al. (2016) who previously examined DOC time changes at 84 ICP Forests plots. They reported no consistent DOC concentration changes in the mineral soil. Our result of decreasing DOC at a depth of 40-80 $\mathrm{cm}$ may have arisen due to differences in the number of plots and spatial coverage; a larger proportion of plots were included from Fennoscandia in this study, where DOC decreased or showed no changes (Clarke and Lindroos, 2010; Wu et al., 2010; Löfgren and Zetterberg, 2011). Many studies attribute changes in DOC to climate effects (Worrall and Burt, 2009), reduced ionic strength (Hruška et al., 2009; Haaland et al., 2010) or acidity (de Wit et al., 2007; Monteith et al., 2007). As climate is less of an influence on DOC in deeper mineral soils, possible explanations include increased adsorption by mineral surfaces due to desorption of $\mathrm{SO}_{4}^{2-}$, or changes in DOC stability as complexation with $\mathrm{Al}$ is decreased, leading to faster DOC decay (Borken et al., 2011).

This article is protected by copyright. All rights reserved. 
For both DOC and acidity, the trends here contrast with those of surface waters reported widely in Europe and North America (e.g. Monteith et al., 2007; Garmo et al., 2014). One reason for the difference is the spatial coverage of the sites. The dataset here includes many forest plots from central Europe not included in studies of acid sensitive surface waters e.g. France, Switzerland, Germany, Italy, Austria, Belgium. It has previously been reported that surface waters in Central Europe had not recovered from acidification to the extent as for other parts of Europe (Alewell et al., 2000b). Secondly, the processes controlling acidity in soil solution and surface waters are different. Soil solution is naturally more acidic due to higher dissolved $\mathrm{CO}_{2}$ and DOC (Reuss and Johnson, 1986). In addition, surface water chemistry is not determined by soil solution leachate alone but integrates contributions from direct runoff, e.g. snow melt and storm events, groundwater and riparian water (Shand et al., 2005; Fuss et al., 2015). The contribution of these components to surface waters varies spatially within catchments and seasonally (Michalzik et al., 2003; James and Roulet et al. 2006; Casson et al., 2014; Fuss et al., 2015). In addition, surface water DOC has been shown to be a function of landscape features such as wetlands and riparian zones, as well as of catchment connectivity and hydrology (Laudon et al., 2011; Knorr, 2013). Organic soils of upper horizons and near-stream zones are considered to be the main sources of dissolved organic matter in headwater catchments (e.g. Brooks et al., 1999; Billett et al., 2006; Evans et al., 2007; Winterdahl et al., 2011) where trends in DOC have been observed in comparison to the mineral soils studied here.

\section{Decline in $\mathrm{NO}_{3}^{-}$in the lower mineral soil}

Another important result was the decrease in $\mathrm{NO}_{3}^{-}$at $40-80 \mathrm{~cm}$ depth. This most likely reflects the $\mathrm{N}$ status of many plots in Western Europe as inorganic N deposition has decreased. Many plots in Germany, Denmark, Belgium and the UK have elevated $\mathrm{NO}_{3}^{-}$in soil solution and as such are considered $\mathrm{N}$ saturated. Numerous studies have shown that decreases in $\mathrm{N}$ deposition have decreased soil solution $\mathrm{NO}_{3}^{-}$(e.g. Boxman et al., 2008; Vanguelova et al., 2010; Verstraeten et al., 2012;

Meesenburg et al., 2016). In contrast to Iost et al. (2012) where no changes were found at most plots,

This article is protected by copyright. All rights reserved. 
the decreasing concentrations here potentially indicate an initial recovery from $\mathrm{N}$ saturation; however, $\mathrm{N}$ critical loads are still exceeded in many areas in Europe (Waldner et al., 2015), a situation that is likely to persist for several decades (Posch et al., 2015). This study was not focused specifically on assessing changes in $\mathrm{N}$ status, and included plots that were strongly $\mathrm{N}$ limited, with $\mathrm{NO}_{3}^{-}$ concentrations close to or below detection limit. As such, a more in-depth examination of $\mathrm{N}$ saturated forests is necessary to evaluate their status.

\section{Acknowledgements}

We gratefully acknowledge the Programme Coordinating Centre of ICP Forests and all observers, technicians and scientists who performed sampling in the field, analyses and data handling. The evaluation was based on data in the UNECE ICP Forests PCC Collaborative Database (see http://icp-forests.net). Data from the following countries (number of plots in parentheses): France (13), Belgium (7), Germany (67), Italy (2), the United Kingdom (8), Ireland (1), Denmark (4), Spain (1), Austria (2), Finland (8), Switzerland (7), Norway (8), and Sweden (42) were part of the analyses. Throughfall and soil solution data in Sweden were collected within the SWETHRO Network. Data from Switzerland were collected in the Swiss Long-term Forest Ecosystem Research programme LWF. We acknowledge Jörg Sintermann (WSL) for the development of a Shiny tool to visualize soil solution chemistry. The Forest Soil Coordinating Centre (FSCC) of ICP Forests provided data from the first Level II soil survey. The long-term collection of forest monitoring data was to a large extent funded by national research institutions and ministries, with support from governmental bodies, services and landowners. It was partially funded by the European Union under the Regulation (EC) No. 2152/2003 concerning monitoring of forests and environmental 
interactions in the Community (Forest Focus) and the project LIFE 07 ENV/D/000218

"Further Development and Implementation of an EU-level Forest Monitoring System

(FutMon)".

\section{References}

Akselsson, C., Hultberg, H., Karlsson, P.E., Pihl Karlsson, G., Hellsten, S., 2013. Acidification trends in south Swedish forest soils 1986-2008 — Slow recovery and high sensitivity to sea-salt episodes.

Science of The Total Environment 444, 271-287.

Alewell, C., Manderscheid, B., Gerstberger, P., Matzner, E., 2000a. Effects of reduced atmospheric deposition on soil solution chemistry and elemental contents of spruce needles in NE-Bavaria, Germany. Journal of Plant Nutrition and Soil Science-Zeitschrift fuer Pflanzenernaehrung und Bodenkunde 163, 509-516.

Alewell, C., Manderscheid, B., Meesenburg, H., Bittersohl, J., 2000b. Is acidification still an ecological threat? Nature 407, 856.

Battles, J.J., Fahey, T.J., Driscoll, C.T., Blum, J.D., Johnson, C.E., 2014. Restoring Soil Calcium Reverses Forest Decline. Environmental Science \& Technology Letters 1, 15-19.

Berger, T.W., Türtscher, S., Berger, P., Lindebner, L., 2016. A slight recovery of soils from Acid Rain over the last three decades is not reflected in the macro nutrition of beech (Fagus sylvatica) at 97 forest stands of the Vienna Woods. Environmental Pollution 216, 624-635.

Billett, M.F., Deacon, C.M., Palmer, S.M., Dawson, J.J.C., Hope, D., 2006. Connecting organic carbon in stream water and soils in a peatland catchment. J. Geophys.Res.: Biogeosci. 111, G02010.

Binkley, D., Fisher, R., 2012. Ecology and management of forest soils. John Wiley \& Sons.

Borken, W., Ahrens, B., Schulz, C., Zimmermann, L., 2011. Site-to-site variability and temporal trends of DOC concentrations and fluxes in temperate forest soils. Global Change Biol 17, 2428 -

This article is protected by copyright. All rights reserved. 
2443.

Bouwman, A.F., Van Vuuren, D.P., Derwent, R.G., Posch, M., 2002. A Global Analysis of Acidification and Eutrophication of Terrestrial Ecosystems. Water, Air, and Soil Pollution 141, 349382.

Boxman, A.W., Peters, R., Roelofs, J.G.M., 2008. Long term changes in atmospheric N and S throughfall deposition and effects on soil solution chemistry in a Scots pine forest in the Netherlands. Environmental Pollution 156, 1252-1259.

Brooks, P.D., Mcknight, D.M., Bencala, K.E., 1999. The relationship between soil heterotrophic activity, soil dissolved organic carbon (DOC) leachate, and catchment-scale DOC export in headwater catchments. Water Resour. Res. 35,1895-1902.

Brumme, R., Meesenburg, H., Bredemeier, M., Jacobsen, C., Schönfelder, E., Meiwes, K.J., Eichhorn, J., 2009. Changes in Soil Solution Chemistry, Seepage Losses, and Input-Output Budgets at Three Beech Forests in Response to Atmospheric Depositions. In: Brumme, R., Khanna, P.K. (Eds.), Functioning and Management of European Beech Ecosystems. Springer Berlin Heidelberg, Berlin, Heidelberg, pp. 303-336.

Camino-Serrano, M., Graf Pannatier, E., Vicca, S., Luyssaert, S., Jonard, M., Ciais, P., Guenet, B., Gielen, B., Penuelas, J., Sardans, J., Waldner, P., Etzold, S., Cecchini, G., Clarke, N., Galic, Z., Gandois, L., Hansen, K., Johnson, J., Klinck, U., Lachmanova, Z., Lindroos, A.J., Meesenburg, H., Nieminen, T.M., Sanders, T.G.M., Sawicka, K., Seidling, W., Thimonier, A., Vanguelova, E., Verstraeten, A., Vesterdal, L., Janssens, I.A., 2016. Trends in soil solution dissolved organic carbon (DOC) concentrations across European forests. Biogeosciences 13, 5567-5585.

Casson, N.J., Eimers, M.C., Watmough, S.A., 2014. Controls on soil nitrification and stream nitrate export at two forested catchments. Biogeochemistry 121, 355-368.

Ciais, P., Schelhaas, M.J., Zaehle, S., Piao, S.L., Cescatti, A., Liski, J., Luyssaert, S., Le-Maire, G., Schulze, E.D., Bouriaud, O., Freibauer, A., Valentini, R., Nabuurs, G.J., 2008. Carbon accumulation in European forests. Nature Geosci 1, 425-429.

This article is protected by copyright. All rights reserved. 
Clarke, N., Lindroos, A.-J., 2010. Concentrations and fluxes of DOC and DON at Level II sites in Norway and Finland. John Derome, 27.

Clarke, N., Zlindra, D., Ulrich, E., Mosello, R., Derome, J., Derome, K., König, N., Lövblad, G., Draaijers, G., Hansen, K., Thimonier, A., Waldner, P., 2016. Part XIV. Sampling and analysis of deposition. In, Manual on methods and criteria for harmonized sampling, assessment, monitoring and analysis of the effects of air pollution on forests. Thünen Institute of Forest Ecosystems, Eberswalde, Germany.

CLRTAP, 2017. Mapping critical loads for ecosystems, Chapter V of Manual on methodologies and criteria for modelling and mapping critical loads and levels and air pollution effects, risks and trends. UNECE Convention on Long-range Transboundary Air Pollution; accessed 01 May 2017 at www.icpmapping.org.

Colette, A., Aas, W., Banin, L., Braban, C.F., Ferm, M., Gonzalez Ortiz, A., Ilyin, I., Mar, K., Pandolfi, M., Putaud, J.-P., 2016. Air pollution trends in the EMEP region between 1990 and 2012. In. Norwegian Institute for Air Research.

Cools, N., De Vos, B., 2011. Availability and evaluation of European forest soil monitoring data in the study on the effects of air pollution on forests. iForest - Biogeosciences and Forestry 4, 205-211. Cronan, C.S., April, R., Bartlett, R.J., Bloom, P.R., Driscoll, C.T., Gherini, S.A., Henderson, G.S., Joslin, J.D., Kelly, J.M., Parnell, R.A., Patterson, H.H., Raynal, D.J., Schaedle, M., Schofield, C.L., Sucoff, E.I., Tepper, H.B., Thornton, F.C., 1989. Aluminum toxicity in forests exposed to acidic deposition: The ALBIOS results. Water, Air, and Soil Pollution 48, 181-192.

De Vries, W., Klap, J.M., Erisman, J.W., 2000. Effects of environmental stress on forest crown condition in Europe. Part I: Hypotheses and approach to the study. Water, Air, and Soil Pollution 119, 317-333.

De Vries, W., Vel, E., Reinds, G.J., Deelstra, H., Klap, J.M., Leeters, E.E.J.M., Hendriks, C.M.A., Kerkvoorden, M., Landmann, G., Herkendell, J., Haussmann, T., Erisman, J.W., 2003. Intensive monitoring of forest ecosystems in Europe: 1 . Objectives, set-up and evaluation strategy. Forest 
Ecology and Management 174, 77-95.

de Wit, H.A., Mulder, J., Hindar, A., Hole, L., 2007. Long-term increase in dissolved organic carbon in streamwaters in Norway is response to reduced acid deposition. Environ. Sci. Technol 41, 77067713.

de Wit, H.A., Eldhuset, T.D., Mulder, J., 2010. Dissolved Al reduces Mg uptake in Norway spruce forest: Results from a long-term field manipulation experiment in Norway. Forest Ecology and Management 259, 2072-2082.

DeHayes, D.H., Schaberg, P.G., Hawley, G.J., Strimbeck, G.R., 1999. Acid Rain Impacts on Calcium Nutrition and Forest Health: Alteration of membrane-associated calcium leads to membrane destabilization and foliar injury in red spruce. BioScience 49, 789-800.

Dentener, F., Drevet, J., Lamarque, J.F., Bey, I., Eickhout, B., Fiore, A.M., Hauglustaine, D., Horowitz, L.W., Krol, M., Kulshrestha, U.C., Lawrence, M., Galy-Lacaux, C., Rast, S., Shindell, D., Stevenson, D., Van Noije, T., Atherton, C., Bell, N., Bergman, D., Butler, T., Cofala, J., Collins, B., Doherty, R., Ellingsen, K., Galloway, J., Gauss, M., Montanaro, V., Müller, J.F., Pitari, G., Rodriguez, J., Sanderson, M., Solmon, F., Strahan, S., Schultz, M., Sudo, K., Szopa, S., Wild, O., 2006. Nitrogen and sulfur deposition on regional and global scales: A multimodel evaluation. Global Biogeochemical Cycles 20, n/a-n/a.

Driscoll, C.T., Lawrence, G.B., Bulger, A.J., Butler, T.J., Cronan, C.S., Eagar, C., Lambert, K.F., Likens, G.E., Stoddard, J.L., Weathers, K.C., 2001. Acidic Deposition in the Northeastern United States: Sources and Inputs, Ecosystem Effects, and Management Strategies: The effects of acidic deposition in the northeastern United States include the acidification of soil and water, which stresses terrestrial and aquatic biota. BioScience 51, 180-198.

Driscoll, C.T., Driscoll, K.M., Fakhraei, H., Civerolo, K., 2016. Long-term temporal trends and spatial patterns in the acid-base chemistry of lakes in the Adirondack region of New York in response to decreases in acidic deposition. Atmospheric Environment 146, 5-14.

EEA, 2016. Emissions of the main air pollutants in Europe. In. European Environment Agency, 
Copenhagen.

Evans, C.D., Freeman, C., Cork, L.G., Thomas, D.N., Reynolds, B., Billett, M.F., Garnett,M.H., Norris, D., 2007. Evidence against recent climate-induced destabilization of soil carbon from 14C analysis of riverine dissolved organic matter. Geophys.Res. Lett. 34, L07407.

Fakhraei, H., Driscoll, C.T., 2015. Proton and Aluminum Binding Properties of Organic Acids in Surface Waters of the Northeastern U.S. Environmental Science \& Technology 49, 2939-2947.

Fakhraei, H., Driscoll, C.T., Renfro, J.R., Kulp, M.A., Blett, T.F., Brewer, P.F., Schwartz, J.S., 2016. Critical loads and exceedances for nitrogen and sulfur atmospheric deposition in Great Smoky Mountains National Park, United States. Ecosphere 7(10):e01466.

Fölster, J., Bringmark, L., Lundin, L., 2003. Temporal and spatial variations in soilwater chemistry at three acid forest sites. Water Air and Soil Pollution 146, 171-195.

Fuss, C.B., Driscoll, C.T., Campbell, J.L., 2015. Recovery from chronic and snowmelt acidification: Long-term trends in stream and soil water chemistry at the Hubbard Brook Experimental Forest, New Hampshire, USA. Journal of Geophysical Research: Biogeosciences 120, 2360-2374.

Futter, M.N., Valinia, S., Löfgren, S., Köhler, S.J., Fölster, J., 2014. Long-term trends in water chemistry of acid-sensitive Swedish lakes show slow recovery from historic acidification. AMBIO 43, $77-90$.

Garmo, Ø.A., Skjelkvåle, B.L., de Wit, H.A., Colombo, L., Curtis, C., Fölster, J., Hoffmann, A., Hruška, J., Høgåsen, T., Jeffries, D.S., Keller, W.B., Krám, P., Majer, V., Monteith, D.T., Paterson, A.M., Rogora, M., Rzychon, D., Steingruber, S., Stoddard, J.L., Vuorenmaa, J., Worsztynowicz, A., 2014. Trends in Surface Water Chemistry in Acidified Areas in Europe and North America from 1990 to 2008. Water, Air, \& Soil Pollution 225, 1880.

Godbold, D.L., Fritz, H.-W., Jentschke, G., Meesenburg, H., Rademacher, P., 2003. Root turnover and root necromass accumulation of Norway spruce (Picea abies) are affected by soil acidity. Tree Physiology 23, 915-921.

This article is protected by copyright. All rights reserved. 
Graf Pannatier, E., Thimonier, A., Schmitt, M., Walthert, L., Waldner, P., 2011. A decade of monitoring at Swiss Long-Term Forest Ecosystem Research (LWF) sites: can we observe trends in atmospheric acid deposition and in soil solution acidity? Environmental monitoring and assessment $174,3-30$.

Gundersen, P., Schmidt, I.K., Raulund-Rasmussen, K., 2006. Leaching of nitrate from temperate forests effects of air pollution and forest management. Environmental reviews 14, 1-57.

Haaland, S., Hongve, D., Laudon, H., Riise, G., Vogt, R.D., 2010. Quantifying the Drivers of the Increasing Colored Organic Matter in Boreal Surface Waters. Environmental Science \& Technology 44, 2975-2980.

Hansen, K., Vesterdal, L., Bastrup-Birk, A., Bille-Hansen, J., 2007. Are Indicators for Critical Load Exceedance Related to Forest Condition? Water Air and Soil Pollution 183, 293-308.

Houle, D., Ouimet, R., Couture, S., Gagnon, C., 2006. Base cation reservoirs in soil control the buffering capacity of lakes in forested catchments. Canadian Journal of Fisheries and Aquatic Sciences 63, 471-474.

Hruška, J., Krám, P., McDowell, W.H., Oulehle, F., 2009. Increased Dissolved Organic Carbon (DOC) in Central European Streams is Driven by Reductions in Ionic Strength Rather than Climate Change or Decreasing Acidity. Environmental Science \& Technology 43, 4320-4326.

Iost, S., Rautio, P., Lindroos, A.J., 2012. Spatio-temporal Trends in Soil Solution Bc/Al and N in Relation to Critical Limits in European Forest Soils. Water Air and Soil Pollution 223, 1467-1479.

James, A. L., Roulet, N. T., 2006. Investigating the applicability of end-member mixing analysis (EMMA) across scale: A study of eight small, nested catchments in a temperate forested watershed, Water Resources Research, 42, W08434

Johnson, J.A., Aherne, J., Cummins, T., 2013. Contrasting responses of two Sitka spruce forest plots in Ireland to reductions in sulphur emissions: results of 20 years of monitoring. Biogeochemistry 116, $15-37$.

This article is protected by copyright. All rights reserved. 
Jonard, M., Fürst, A., Verstraeten, A., Thimonier, A., Timmermann, V., Potočić, N., Waldner, P., Benham, S., Hansen, K., Merilä, P., Ponette, Q., de la Cruz, A.C., Roskams, P., Nicolas, M., Croisé, L., Ingerslev, M., Matteucci, G., Decinti, B., Bascietto, M., Rautio, P., 2015. Tree mineral nutrition is deteriorating in Europe. Global Change Biol 21, 418-430.

Khanna, P., Prenzel, J., Meiwes, K., Ulrich, B., Matzner, E., 1987. Dynamics of sulfate retention by acid forest soils in an acidic deposition environment. Soil Science Society of America Journal 51, $446-452$.

Knorr, K.H., 2013. DOC-dynamics in a small headwater catchment as driven by redox fluctuations and hydrological flow paths - are DOC exports mediated by iron reduction/oxidation cycles? Biogeosciences 10, 891-904.

Kristensen, H.L., Gundersen, P., Callesen, I., Reinds, G.J., 2004. Throughfall Nitrogen Deposition Has Different Impacts on Soil Solution Nitrate Concentration in European Coniferous and Deciduous Forests. Ecosystems 7, 180-192.

König, N., Cools, N., Derome, K., Kowalska, A., De Vos, B., Fürst, A., Marchetto, A., O'Dea, P., Tartari, G.A., 2013. Chapter 22 - Data Quality in Laboratories: Methods and Results for Soil, Foliar, and Water Chemical Analyses. In: Ferretti, M., Fischer, R. (Eds.), Developments in Environmental Science. Elsevier, pp. 415-453.

Kvaalen, H., Solberg, S., Clarke, N., Torp, T., Aamlid, D., 2002. Time series study of concentrations of $\mathrm{SO}_{4}{ }^{2-}$ and $\mathrm{H}^{+}$in precipitation and soil waters in Norway. Environmental Pollution 117, 215-224.

Lange, H., Solberg, S., Clarke, N., 2006. Aluminum dynamics in forest soil waters in Norway. Science of the total environment 367, 942-957.

Larssen, T., Duan, L., Mulder, J., 2011. Deposition and Leaching of Sulfur, Nitrogen and Calcium in Four Forested Catchments in China: Implications for Acidification. Environmental Science \& Technology 45, 1192-1198.

Laudon, H., Berggren, M., Ågren, A., Buffam, I., Bishop, K., Grabs, T., Jansson, M., Köhler, S., 2011. Patterns and Dynamics of Dissolved Organic Carbon (DOC) in Boreal Streams: The Role of

This article is protected by copyright. All rights reserved. 
Processes, Connectivity, and Scaling. Ecosystems 14, 880-893.

Lawrence, G.B., Hazlett, P.W., Fernandez, I.J., Ouimet, R., Bailey, S.W., Shortle, W.C., Smith, K.T., Antidormi, M.R., 2015. Declining Acidic Deposition Begins Reversal of Forest-Soil Acidification in the Northeastern U.S. and Eastern Canada. Environmental Science \& Technology 49, 13103-13111.

Levene, H., 1960. Robust test for equality of variances. In: Olkin, I. (Ed.), Contributions to Probability and Statistics: Essays in Honor of Harold Hotelling. Stanford University Press, Standford, CA, pp. 278-292.

Liu, K.-H., Fang, Y.-T., Yu, F.-M., Liu, Q., Li, F.-R., Peng, S.-L., 2010. Soil Acidification in Response to Acid Deposition in Three Subtropical Forests of Subtropical China. Pedosphere 20, 399408.

Liu, X., Duan, L., Mo, J., Du, E., Shen, J., Lu, X., Zhang, Y., Zhou, X., He, C., Zhang, F., 2011. Nitrogen deposition and its ecological impact in China: An overview. Environmental Pollution 159, 2251-2264.

Liu, X., Zhang, Y., Han, W., Tang, A., Shen, J., Cui, Z., Vitousek, P., Erisman, J.W., Goulding, K., Christie, P., Fangmeier, A., Zhang, F., 2013. Enhanced nitrogen deposition over China. Nature 494, 459.

Lomský, B., Šrámek, V., Novotný, R., 2012. Changes in the air pollution load in the Jizera Mts.: effects on the health status and mineral nutrition of the young Norway spruce stands. European Journal of Forest Research 131, 757-771.

Lorenz, M., 2010. Objectives, Strategy and Implementation of ICP Forests. Manual. In, Manual on methods and criteria for harmonized sampling, assessment, monitoring and analysis of the effects of air pollution on forests. UNECE, ICP Forests, Hamburg, p. 22.

Löfgren, S., Zetterberg, T., 2011. Decreased DOC concentrations in soil water in forested areas in southern Sweden during 1987-2008. The Science of the Total Environment 409, 1916-1926.

Löfgren, S., Aastrup, M., Bringmark, L., Hultberg, H., Lewin-Pihlblad, L., Lundin, L., Karlsson, G.P., 
Thunholm, B., 2011. Recovery of soil water, groundwater, and streamwater from acidification at the Swedish Integrated Monitoring catchments. Ambio 40, 836-856.

Marchetto, A., Mosello, R., Tartari, G., Derome, J., Derome, K., König, N., Clarke, N., Kowalska, A., 2009. Atmospheric Deposition and Soil Solution Working Ring Test 2009. In, Project FutMon.

C.N.R. Institute of Ecosystem Study, Verbania Pallanza.

Matschonat, G., Vogt, R., 1998. Significance of the total cation concentration in acid forest soils for the solution composition and the saturation of exchange sites. Geoderma 84, 289-307.

Meesenburg, H., Ahrends, B., Fleck, S., Wagner, M., Fortmann, H., Scheler, B., Klinck, U., Dammann, I., Eichhorn, J., Mindrup, M., Meiwes, K.J., 2016. Long-term changes of ecosystem services at Solling, Germany: Recovery from acidification, but increasing nitrogen saturation? Ecological Indicators 65, 103-112.

Michalzik, B., Tipping, E., Mulder, J., Lancho, J.F.G., Matzner, E., Bryant, C.L., Clarke, N., Lofts, S., Esteban, M.A.V., 2003. Modelling the production and transport of dissolved organic carbon in forest soils. Biogeochemistry 66, 241-264.

Mitchell, M.J., Likens, G.E., 2011. Watershed Sulfur Biogeochemistry: Shift from Atmospheric Deposition Dominance to Climatic Regulation. Environmental Science \& Technology 45, 5267-5271. Monteith, D.T., Stoddard, J.L., Evans, C.D., de Wit, H.A., Forsius, M., Høgåsen, T., Wilander, A., Skjelkvåle, B.L., Jeffries, D.S., Vuorenmaa, J., 2007. Dissolved organic carbon trends resulting from changes in atmospheric deposition chemistry. Nature 450, 537-540.

Nieminen, T., De Vos, B., Cools, N., Koenig, N., Fischer, R., Iost, S., Meesenburg, H., Nicholas, M.P., Cecchini, G., Ferretti, M., de la Cruz, A.C., Derome, K., Lindroos, A.J., Graf Pannatier, E., 2016. Part XI: Soil solution collection and analysis. In. Manual on methods and criteria for harmonized sampling, assessment, monitoring and analysis of the effects of air pollution on forests. Thünen Institute of Forest Ecosystems, Eberswalde, Germany, p. 29.

Oulehle, F., Hofmeister, J., Cudlín, P., Hruŝka, J., 2006. The effect of reduced atmospheric deposition on soil and soil solution chemistry at a site subjected to long-term acidification, Načetín, Czech

This article is protected by copyright. All rights reserved. 
Republic. Science of the Total Environment 370, 532-544.

Oulehle, F., Evans, C.D., Hofmeister, J., Krejci, R., Tahovska, K., Persson, T., Cudlin, P., Hruska, J., 2011. Major changes in forest carbon and nitrogen cycling caused by declining sulphur deposition. Global Change Biology 17(10), 3115-3129.

Pihl Karlsson, G., Akselsson, C., Hellsten, S., Karlsson, P.E., 2011. Reduced European emissions of S and $\mathrm{N}$-effects on air concentrations, deposition and soil water chemistry in Swedish forests.

Environmental Pollution 159, 3571-3582.

Posch, M., Duan, L., Reinds, G.J., Zhao, Y., 2015. Critical loads of nitrogen and sulphur to avert acidification and eutrophication in Europe and China. Landscape Ecology 30, 487-499.

Prechtel, A., Alewell, C., Armbruster, M., Bittersohl, J., Cullen, J.M., Evans, C.D., Helliwell, R., Kopácek, J., Marchetto, A., Matzner, E., Meesenburg, H., Moldan, F., Moritz, K., Veselý, J., Wright, R.F., 2001. Response of sulphur dynamics in European catchments to decreasing sulphate deposition. Hydrol. Earth Syst. Sci. 5, 311-326.

Reinds, G.J., Posch, M., Leemans, R., 2009. Modelling recovery from soil acidification in European forests under climate change. Science of the Total Environment 407, 5663-5673.

Reuss, J.O., Johnson, D.W., 1986. Acid deposition and the acidification of soils and waters. Springer Science \& Business Media, New York.

Sawicka, K., Monteith, D., Vanguelova, E., Wade, A.J., Clark, J.M., 2016. Fine-scale temporal characterization of trends in soil water dissolved organic carbon and potential drivers. Ecological Indicators 68, 36-51.

Shand, P., Haria, A.H., Neal, C., Griffiths, K., Gooddy, D., Dixon, A.J., Hill, T., Buckley, D.K., Cunningham, J., 2005. Hydrochemical heterogeneity in an upland catchment: further characterisation of the spatial, temporal and depth variations in soils, streams and groundwaters of the Plynlimon forested catchment, Wales. Hydrology and Earth System Sciences, 9 (6). 621-644.

Skjelkvåle, B.L., Borg, H., Hindar, A., Wilander, A., 2007. Large scale patterns of chemical recovery 
in lakes in Norway and Sweden: Importance of seasalt episodes and changes in dissolved organic carbon. Applied Geochemistry 22, 1174-1180.

Sokolova, T.A., Alekseeva, S.A., 2008. Adsorption of sulfate ions by soils (A Review). Eurasian Soil Science 41, 140-148.

Stoddard, J., Jeffries, D., Lükewille, A., Clair, T., Dillon, P. J., Driscoll, C. T., Forsius, M., Johannessen, M., Kahl, J. S., Kellogg, J. H., Kemp, A., Mannio, J., Monteith, D. T., Murdoch, P. S., Patrick, S., Rebsdorf, A., Skjelkvåle, B. L., Stainton, M. P., Traaen, T., van Dam, H., Webster, K. E., Wieting J., Wilander A., 1999. Regional trends in aquatic recovery from acidification in North America and Europe. Nature 401, 575-578.

Stoddard, J.L., 1994. Long-Term Changes in Watershed Retention of Nitrogen: Its Causes and Aquatic Consequences. In. Environmental Chemistry of Lakes and Reservoirs. American Chemical Society, 223-284.

Strock, K.E., Nelson, S.J., Kahl, J.S., Saros, J.E., McDowell, W.H., 2014. Decadal Trends Reveal Recent Acceleration in the Rate of Recovery from Acidification in the Northeastern U.S. Environmental Science \& Technology 48, 4681-4689.

Sullivan, T.J., Lawrence, G.B., Bailey, S.W., McDonnell, T.C., Beier, C.M., Weathers, K.C., McPherson, G.T., Bishop, D.A., 2013. Effects of Acidic Deposition and Soil Acidification on Sugar Maple Trees in the Adirondack Mountains, New York. Environmental Science \& Technology 47, $12687-12694$.

Sverdrup, H., Warfvinge, P., 1993. The effect of soil acidification on the growth of trees, grass and herbs as expressed by the $(\mathrm{Ca}+\mathrm{Mg}+\mathrm{K}) / \mathrm{Al}$ ratio. In, Reports in ecology and environmental engineering 2. Department of Chemical Engineering II, Lund University, Sweden, p. 178.

Ukonmaanaho, L., Starr, M., Lindroos, A.-J., Nieminen, T.M., 2014. Long-term changes in acidity and DOC in throughfall and soil water in Finnish forests. Environmental Monitoring and Assessment $186,7733-7752$.

Ulrich, B., 1983. Soil acidity and its relations to acid deposition. In: Ulrich, B., J, P. (Eds.), Effects of

This article is protected by copyright. All rights reserved. 
accumulation of air pollutants in forest ecosystems. D. Reidel Publishing Company, Dordrecht, pp. 127-146.

van der Heijden, G., Legout, A., Nicolas, M., Ulrich, E., Johnson, D.W., Dambrine, E., 2011. Longterm sustainability of forest ecosystems on sandstone in the Vosges Mountains (France) facing atmospheric deposition and silvicultural change. Forest Ecology and Management 261, 730-740.

Vanguelova, E.I., Hirano, Y., Eldhuset, T.D., Sas-Paszt, L., Bakker, M.R., Püttsepp, Ü., Brunner, I., Lõhmus, K., Godbold, D., 2007a. Tree fine root Ca/Al molar ratio - Indicator of Al and acidity stress. Plant Biosystems - An International Journal Dealing with all Aspects of Plant Biology 141, 460-480. Vanguelova, E.I., Nortcliff, S., Moffat, A.J., Kennedy, F., 2007b. Short-term effects of manipulated increase in acid deposition on soil, soil solution chemistry and fine roots in Scots pine (Pinus sylvestris) stand on a podzol. Plant and Soil 294, 41-54.

Vanguelova, E.I., Benham, S., Pitman, R., Moffat, A.J., Broadmeadow, M., Nisbet, T., Durrant, D., Barsoum, N., Wilkinson, M., Bochereau, F., Hutchings, T., Broadmeadow, S., Crow, P., Taylor, P., Houston, T.D., 2010. Chemical fluxes in time through forest ecosystems in the UK - Soil response to pollution recovery. Environmental Pollution 158, 1857-1869.

Verstraeten, A., Neirynck, J., Genouw, G., Cools, N., Roskams, P., Hens, M., 2012. Impact of declining atmospheric deposition on forest soil solution chemistry in Flanders, Belgium. Atmospheric Environment 62, 50-63.

Verstraeten, A., De Vos, B., Neirynck, J., Roskams, P., Hens, M., 2014. Impact of air-borne or canopy-derived dissolved organic carbon (DOC) on forest soil solution DOC in Flanders, Belgium. Atmospheric environment 83, 155-165.

Waldner, P., Marchetto, A., Thimonier, A., Schmitt, M., Rogora, M., Granke, O., Mues, V., Hansen, K., Pihl Karlsson, G., Žlindra, D., Clarke, N., Verstraeten, A., Lazdins, A., Schimming, C., Iacoban, C., Lindroos, A.-J., Vanguelova, E., Benham, S., Meesenburg, H., Nicolas, M., Kowalska, A., Apuhtin, V., Napa, U., Lachmanová, Z., Kristoefel, F., Bleeker, A., Ingerslev, M., Vesterdal, L., Molina, J., Fischer, U., Seidling, W., Jonard, M., O'Dea, P., Johnson, J., Fischer, R., Lorenz, M., 
2014. Detection of temporal trends in atmospheric deposition of inorganic nitrogen and sulphate to forests in Europe. Atmospheric Environment 95, 363-374.

Waldner, P., Thimonier, A., Graf Pannatier, E., Etzold, S., Schmitt, M., Marchetto, A., Rautio, P., Derome, K., Nieminen, T.M., Nevalainen, S., Lindroos, A.-J., Merilä, P., Kindermann, G., Neumann, M., Cools, N., de Vos, B., Roskams, P., Verstraeten, A., Hansen, K., Pihl Karlsson, G., Dietrich, H.P., Raspe, S., Fischer, R., Lorenz, M., Iost, S., Granke, O., Sanders, T.G.M., Michel, A., Nagel, H.-D., Scheuschner, T., Simončič, P., von Wilpert, K., Meesenburg, H., Fleck, S., Benham, S., Vanguelova, E., Clarke, N., Ingerslev, M., Vesterdal, L., Gundersen, P., Stupak, I., Jonard, M., Potočić, N., Minaya, M., 2015. Exceedance of critical loads and of critical limits impacts tree nutrition across Europe. Annals of Forest Science 72, 929-939.

Warby, R.A.F., Johnson, C.E., Driscoll, C.T., 2005. Chemical Recovery of Surface Waters Across the Northeastern United States from Reduced Inputs of Acidic Deposition: 1984-2001. Environmental Science \& Technology 39, 6548-6554.

Watmough, S.A., Aherne, J., Alewell, C., Arp, P., Bailey, S., Clair, T., Dillon, P., Duchesne, L., Eimers, C., Fernandez, I., Foster, N., Larssen, T., Miller, E., Mitchell, M., Page, S., 2005. Sulphate, Nitrogen and Base Cation Budgets at 21 Forested Catchments in Canada, the United States and Europe. Environmental Monitoring and Assessment 109, 1-36.

Watmough, S.A., Eimers, C., Baker, S., 2016. Impediments to recovery from acid deposition. Atmospheric Environment 146, 15-27.

Wellbrock, N., \& Bolte, A. Flessa, H., (Eds.) 2016. Dynamics and Spatial Patterns of Forest Sites in Germany: Results of Soil Forest Surveys 2006 to 2008. Thünen Reports 43, Thünen Institute, Germany

Winterdahl, M., Futter, M., Köhler, S., Laudon, H., Seibert, J., Bishop, K.C.W., 2011.Riparian soil temperature modification of the relationship between flow and dissolved organic carbon concentration in a boreal stream. Water Resour. Res.47,

Worrall, F., Burt, T.P., 2009. Changes in DOC treatability: Indications of compositional changes in 
DOC trends. Journal of Hydrology 366, 1-8.

Wu, Y., Clarke, N., Mulder, J., 2010. Dissolved organic carbon concentrations in throughfall and soil waters at Level II monitoring plots in Norway: short-and long-term variations. Water, air, and soil pollution 205, 273-288.

Zhu, Q., De Vries, W., Liu, X., Zeng, M., Hao, T., Du, E., Zhang, F., Shen, J., 2016. The contribution of atmospheric deposition and forest harvesting to forest soil acidification in China since 1980.

Atmospheric Environment 146, 215-222.

This article is protected by copyright. All rights reserved. 


\section{Tables}

Table 1 Soil $\mathrm{pH}_{\mathrm{CaCl}_{2}}$ and base saturation (BSat) summary statistics of soil survey (1990-2000).

\begin{tabular}{cccccccc}
\hline Layer & Variable & Min. & Median & Mean & Max. & n & no data \\
\hline \multirow{2}{*}{$10-20 \mathrm{~cm}$} & $\mathrm{pH}_{\mathrm{CaCl}_{2}}$ & 2.7 & 3.9 & 4.0 & 7.2 & 100 & 4 \\
& $\mathrm{BSat}(\%)$ & 2 & 11 & 23 & 100 & 98 & 6 \\
\hline \multirow{2}{*}{$40-80 \mathrm{~cm}$} & $\mathrm{pH}_{\mathrm{CaCl}_{2}}$ & 3.3 & 4.4 & 4.6 & 7.6 & 145 & 17 \\
& $\mathrm{BSat}(\%)$ & 2 & 20 & 34 & 100 & 136 & 26 \\
\hline
\end{tabular}

This article is protected by copyright. All rights reserved. 
Table 2 Environmental factors included as stratifying factors in the linear mixed-effects model. The model tested if soil solution trends were different between factor levels.

\begin{tabular}{l|c|c|}
\hline \multicolumn{1}{|l|}{ Factor } & Soil depth & Levels \\
\hline Region & & $\begin{array}{c}\text { West, Central, North } \\
\text { Deciduous, Coniferous }\end{array}$ \\
\hline Soil Chemistry & $10-20 \mathrm{~cm}$ & $\leq 4.0,>4.0$ \\
\hline pH $\left(\mathrm{CaCl}_{2}\right)$ & $40-80 \mathrm{~cm}$ & $\leq 4.5,>4.5$ \\
\hline BSat $(\%)$ & $10-20 \mathrm{~cm}$ & $\leq 10,>10$ \\
& $40-80 \mathrm{~cm}$ & $\leq 20,>20$ \\
\hline
\end{tabular}

Throughfall trend

\begin{tabular}{|l|c|c|}
\hline & $\begin{array}{c}\text { Relative change for a } \\
\text { ten-year period \% }\end{array}$ & $\begin{array}{c}\text { Absolute change for } \\
\text { ten years }\left(\mu \mathrm{eq} \mathrm{L} \mathrm{L}^{-1}\right.\end{array}$ \\
\hline $\mathrm{SO}_{4}{ }^{2-}$ & $<, \geq-60$ & $<, \geq-40$ \\
$\mathrm{Bc}$ & $<, \geq-11$ & $<, \geq-10$ \\
$\mathrm{~N}$ inorg & $<, \geq-22$ & $<, \geq-13$ \\
$\mathrm{Ac}_{\text {pot }}$ & & $<, \geq-46$ \\
\hline
\end{tabular}

This article is protected by copyright. All rights reserved. 
Table 3 Summary statistics $\left(5^{\text {th }}\right.$, median, $95^{\text {th }}$ percentile) of the intercept of the linear model applied to individual plots. The intercept represents the value in the year $2000 . \mathrm{Bc}^{\mathrm{Al}} \mathrm{l}_{\text {tot }}$ is the molar ratio of nutrient base cations $\left(\mathrm{Ca}^{2+}+\mathrm{Mg}^{2+}+\mathrm{K}^{+}\right)$to total $\mathrm{Al}$.

\begin{tabular}{c|c|ccc|ccc}
\hline & & \multicolumn{3}{|c|}{$10-20 \mathrm{~cm}$} & \multicolumn{3}{c}{$40-80 \mathrm{~cm}$} \\
\hline $\mathrm{pH}$ & $5^{\text {th }}$ & Median & $95^{\text {th }}$ & $5^{\text {th }}$ & Median & $95^{\text {th }}$ \\
\hline $\mathrm{Ca}^{2+}$ & & 3.7 & 4.6 & 7.0 & 4.1 & 4.8 & 7.7 \\
$\mathrm{Mg}^{2+}$ & & 10 & 96 & 720 & 11 & 74 & 2039 \\
$\mathrm{~K}^{+}$ & & 12 & 59 & 245 & 9 & 61 & 464 \\
$\mathrm{Na}^{+}$ & $\mu \mathrm{eq} \mathrm{L}$ & 2 & 12 & 73 & 2 & 11 & 69 \\
$\mathrm{Cl}^{-}$ & & 20 & 84 & 373 & 22 & 123 & 631 \\
$\mathrm{NO}_{3}^{-}$ & & 14 & 94 & 541 & 13 & 106 & 702 \\
$\mathrm{SO}_{4}^{2-}$ & & 16 & 441 & 1 & 7.2 & 583 \\
$\mathrm{ANC}^{-1}$ & & 41 & 131 & 464 & 37 & 212 & 739 \\
\hline $\mathrm{Al}_{\text {tot }}$ & mg L & -531 & -47 & 489 & -569 & -26 & 2414 \\
$\mathrm{DOC}^{-1}$ & 0.03 & 1.00 & 4.2 & 0.02 & 0.8 & 5.7 \\
\hline $\mathrm{Bc}^{2} \mathrm{Al} l_{\text {tot }}$ & & 1.4 & 12 & 42 & 1.2 & 5.8 & 29 \\
\hline
\end{tabular}

This article is protected by copyright. All rights reserved. 
Table 4 Temporal trends in soil solution at the European scale. The change in concentration for a ten-year period is shown relative to the year 2000 and as absolute value. $\mathrm{Bc}: \mathrm{Al}_{\text {tot }}$ trends are shown for soils with soil $\mathrm{pH}_{\mathrm{CaCl}}<5.0 . \mathrm{Bc}=\Sigma\left(\mathrm{Ca}^{2+}+\mathrm{Mg}^{2+}+\mathrm{K}^{+}\right), \mathrm{AA}^{2}=\Sigma\left(\mathrm{SO}_{4}^{2-}+\mathrm{NO}_{3}^{-}+\mathrm{Cl}^{-}\right)$. $\mathrm{Note}^{2}$ trends in Bc, AA or ANC differ from the sum of individual ions as not all-time series had complete ions for all months and years.

\begin{tabular}{|c|c|c|c|c|c|c|c|}
\hline \multirow[b]{3}{*}{ Variable } & \multirow[b]{3}{*}{ Unit } & \multicolumn{3}{|c|}{$10-20 \mathrm{~cm}$} & \multicolumn{3}{|c|}{$40-80 \mathrm{~cm}$} \\
\hline & & \multirow[b]{2}{*}{ Significance } & \multicolumn{2}{|c|}{ Ten year change } & \multirow[b]{2}{*}{ Significance } & \multicolumn{2}{|c|}{ Ten year change } \\
\hline & & & $\begin{array}{c}\text { Relative to } \\
2000(\%)\end{array}$ & Absolute & & $\begin{array}{c}\text { Relative to } \\
2000(\%)\end{array}$ & Absolute \\
\hline $\mathrm{pH}$ & & ns & +1.0 & +0.05 & ns & +1.2 & +0.07 \\
\hline $\mathrm{Ca}^{2+}$ & \multirow{10}{*}{$\mu e q L^{-1}$} & $* * *$ & -55 & -57 & $* * *$ & -58 & -68 \\
\hline $\mathrm{Mg}^{2+}$ & & $* *$ & -35 & -24 & $*$ & -28 & -18 \\
\hline $\mathrm{K}^{+}$ & & $* *$ & -57 & -7.1 & $* *$ & -32 & -3.5 \\
\hline $\mathrm{Na}^{+}$ & & ns & -9 & -8.4 & ns & -6 & -7.5 \\
\hline $\mathrm{SO}_{4}^{2-}$ & & $* *$ & -52 & -61 & $* * *$ & -40 & -69 \\
\hline $\mathrm{NO}_{3}^{-}$ & & ns & -14 & -2.3 & $(*)$ & -30 & -4.2 \\
\hline $\mathrm{Cl}^{-}$ & & ns & -9 & -8.8 & ns & -5 & -6.1 \\
\hline $\mathrm{Bc}+\mathrm{Na}^{+}$ & & $* * *$ & -31 & -110 & $*$ & -30 & -143 \\
\hline $\mathrm{AA}$ & & $* * *$ & -34 & -110 & $* * *$ & -28 & -116 \\
\hline ANC & & ns & -5 & -19 & ns & -19 & -36 \\
\hline $\mathrm{Al}_{\text {tot }}$ & \multirow{2}{*}{$\mathrm{mg} \mathrm{L}^{-1}$} & $* *$ & -19 & -0.13 & $*$ & -17 & -0.08 \\
\hline DOC & & ns & -4 & -0.44 & $*$ & -17 & -1.14 \\
\hline \multicolumn{2}{|c|}{$\mathrm{Bc}: \mathrm{Al}_{\text {tot }}\left(\right.$ soil $\left.\mathrm{pH}_{\mathrm{CaCl}_{2}}<5.0\right)$} & ns & -18 & -0.30 & ns & -11 & -0.23 \\
\hline
\end{tabular}

*** $p<0.001,{ }^{* *} p<0.01,{ }^{*} p<0.05,\left(^{*}\right) p<0.1, \mathrm{~ns}=$ not significant

This article is protected by copyright. All rights reserved. 
Table 5 Trends in soil solution stratified by environmental factors. Only trends that were significantly different between factor levels are shown.

For throughfall $\mathrm{SO}_{4}^{2-}$, the magnitude of the change is for a ten-year period. Significance for each factor level is indicated as follows: ${ }^{* * *} p<0.001$,

${ }^{* *} p<0.01,{ }^{*} p<0.05,\left({ }^{*}\right) p<0.1$, ns $=$ not significant

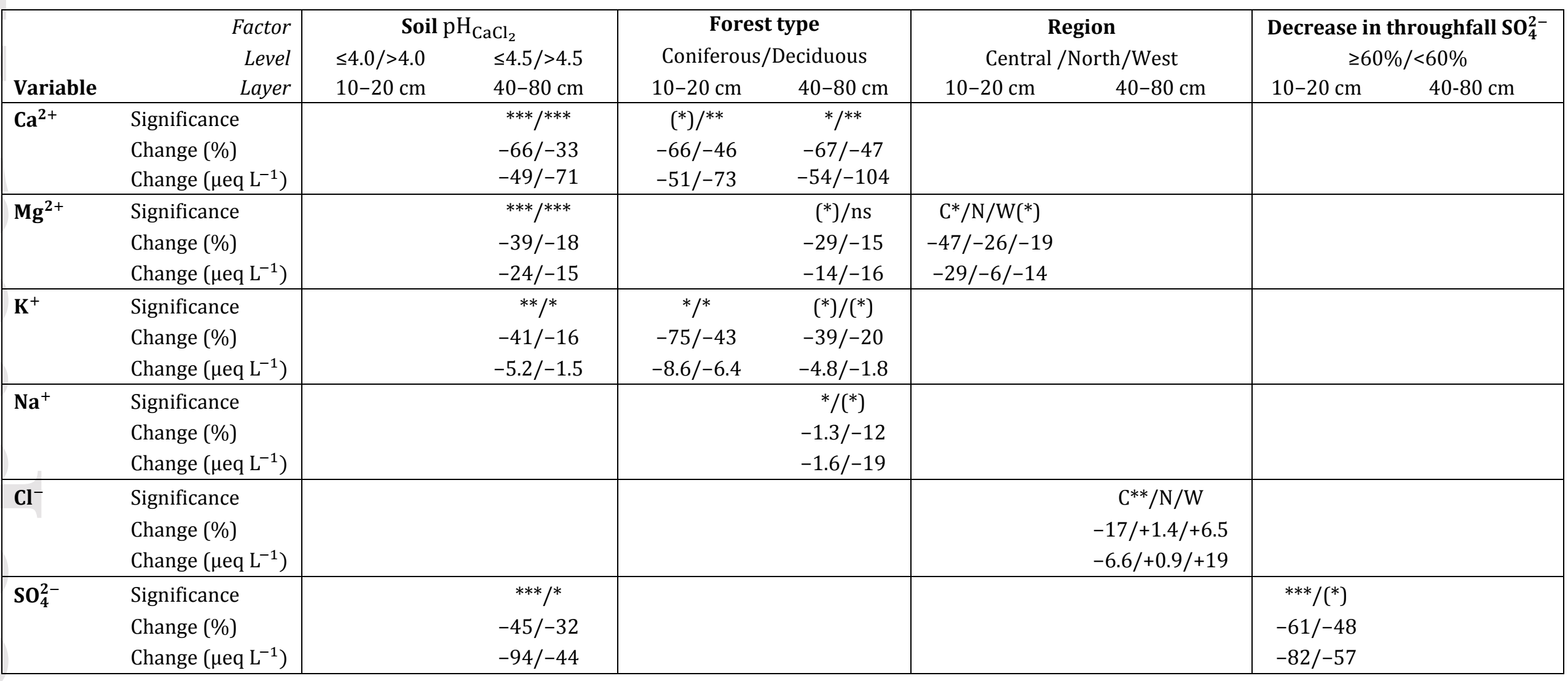

This article is protected by copyright. All rights reserved. 


\begin{tabular}{|c|c|c|c|c|c|}
\hline $\mathrm{NO}_{3}^{-}$ & $\begin{array}{l}\text { Significance } \\
\text { Change (\%) } \\
\text { Change }\left(\mu \mathrm{eq} \mathrm{L} \mathrm{L}^{-1}\right)\end{array}$ & $\begin{array}{c}* / * \\
-50 /-1.6 \\
-6.1 /-0.2 \\
\end{array}$ & & & \\
\hline $\mathrm{Al}_{\text {tot }}$ & $\begin{array}{l}\text { Significance } \\
\text { Change (\%) } \\
\text { Change }\left(\mathrm{mg} \mathrm{L}^{-1}\right)\end{array}$ & $\begin{array}{c}* * * / * * * \\
-34 /-2 \\
-0.4 /-0.003 \\
\end{array}$ & $\begin{array}{c}* * / \mathrm{ns} \\
-29 /-3 \\
-0.28 /-0.01\end{array}$ & $\begin{array}{c}\mathrm{C}^{* *} / \mathrm{N}\left({ }^{*}\right) / \mathrm{W}^{*} \\
-43 /+0.3 /-20 \\
-0.15 /+0.001 / \\
-0.07 \\
\end{array}$ & $\begin{array}{c}\left.\mathrm{ns} / \mathrm{(}^{*}\right) \\
-28 /-12 \\
-0.22 /-0.04 \\
\end{array}$ \\
\hline pH & $\begin{array}{l}\text { Significance } \\
\text { Change (\%) } \\
\text { Change (pH unit) }\end{array}$ & & & & \\
\hline DOC & $\begin{array}{l}\text { Significance } \\
\text { Change (\%) } \\
\text { Change }\left(\mathrm{mg} \mathrm{L}^{-1}\right)\end{array}$ & & & $\begin{array}{c}\mathrm{C}^{* *} / \mathrm{N} / \mathrm{W}^{* *} \\
-4.8 /-15 /-27 \\
-0.2 /-0.8 /-2.9 \\
\end{array}$ & \\
\hline Bc & $\begin{array}{l}\text { Significance } \\
\text { Change (\%) } \\
\text { Change }\left(\mu \mathrm{eq} \mathrm{L} \mathrm{L}^{-1}\right)\end{array}$ & $\begin{array}{c}* * * / * * * \\
-53 /-27 \\
-92 /-106 \\
\end{array}$ & $\begin{array}{c}(*) / * * \\
-45 /-32 \\
-80 /-133 \\
\end{array}$ & & \\
\hline AA & $\begin{array}{l}\text { Significance } \\
\text { Change (\%) } \\
\text { Change }\left(\mu \mathrm{eq} \mathrm{L}^{-1}\right)\end{array}$ & $\begin{array}{c}* * * / * \\
-32 /-19 \\
-149 /-67 \\
\end{array}$ & & & \\
\hline $\mathbf{B c}: \mathbf{A l}_{\text {tot }}$ & $\begin{array}{l}\text { Significance } \\
\text { Change (\%) } \\
\text { Change } \\
\text { (absolute) } \\
\end{array}$ & & & & \\
\hline ANC & $\begin{array}{l}\text { Significance } \\
\text { Change }(\%) \\
\text { Change }\left(\mu \mathrm{eq} \mathrm{L} \mathrm{L}^{-1}\right)\end{array}$ & $\begin{array}{c}\mathrm{ns} /{ }^{* *} \\
+23 /-16 \\
+40 /-118\end{array}$ & $\begin{array}{c}* * /\left({ }^{*}\right) \\
+40 /-29 \\
+14 /-165\end{array}$ & & $\begin{array}{c}\text { ns/* } \\
+179 /-29 \\
+10 /-119\end{array}$ \\
\hline
\end{tabular}

This article is protected by copyright. All rights reserved. 


\section{Figure Captions}

Fig. 1 Location of the Level II ICP Forests plots included in the study, left plots at 10-20 cm soil depth and right at $40-80 \mathrm{~cm}$ soil depth.

Fig. 2 Median concentrations at 10-20 $\mathrm{cm}$ for selected variables with the trend from the linear model superimposed. The model was run for the period 1995-2012, but to be consistent, the period displayed is for years that had at least 75 plots. Significance is indicated as: ${ }^{* * *} p<0.001,{ }^{*} p<0.01,{ }^{*} p<0.05,\left({ }^{*}\right)$ $p<0.1$. Boxplot whiskers represent 0.75 times the interquartile range.

Fig. 3 Median concentrations at 40-80 $\mathrm{cm}$ for selected variables with the trend from the linear model superimposed. The model was run for the period 1995-2012, but to be consistent, the period displayed is for years that had at least 120 plots. Significance is indicated as: ${ }^{* *} p<0.001,{ }^{* *} p<0.01,{ }^{*} p<0.05$, $\left.{ }^{*}\right) p<0.1$. Boxplot whiskers represent 0.75 times the interquartile range 


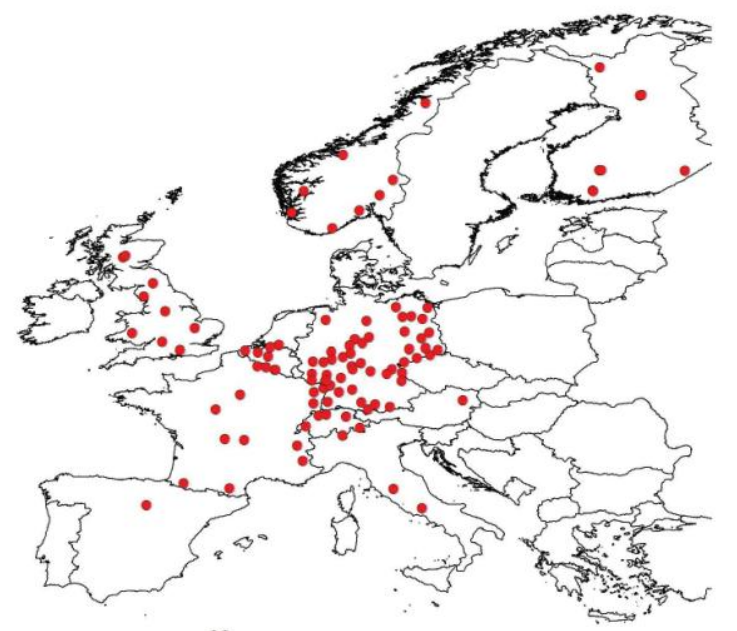

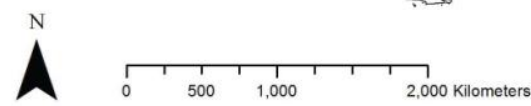

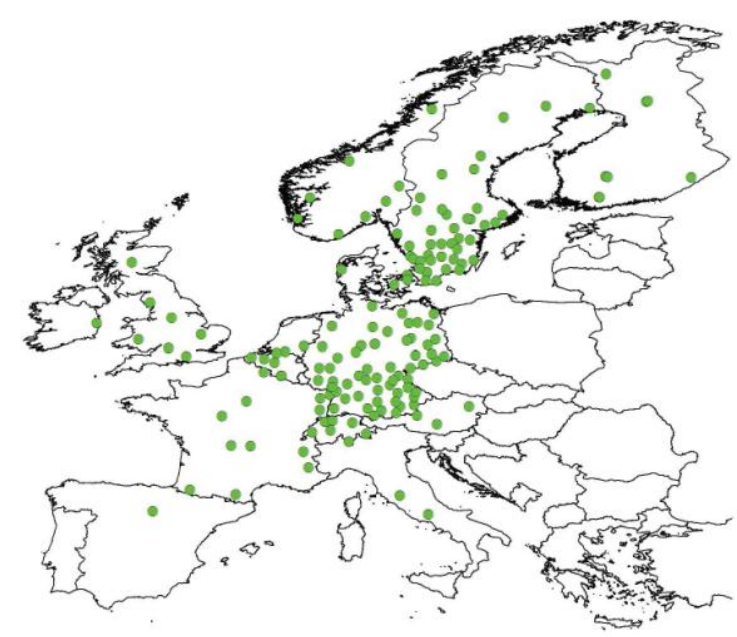

Projection: Lambert-Azimuthal

This article is protected by copyright. All rights reserved. 
$10-20 \mathrm{~cm}$
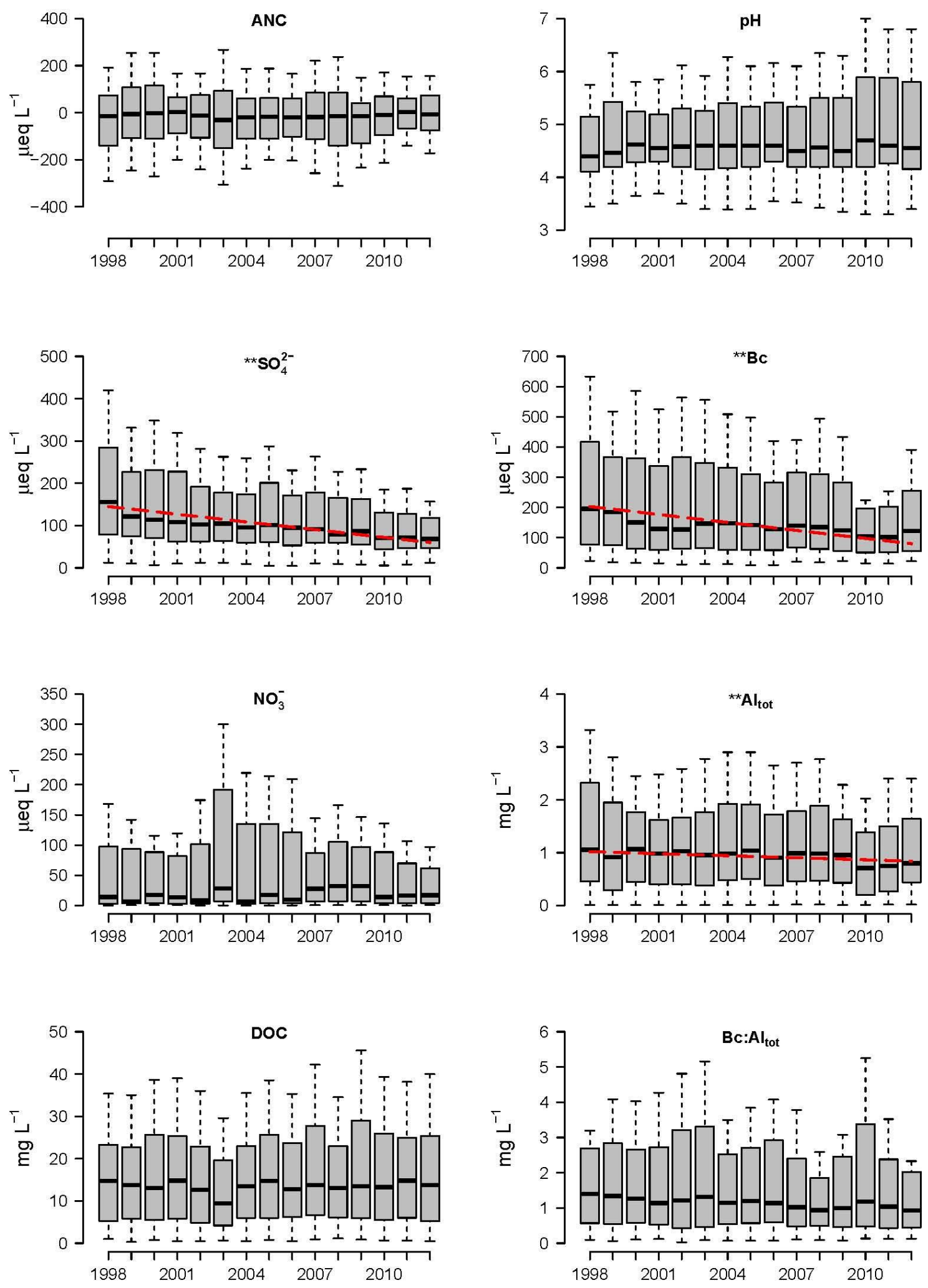

This article is protected by copyright. All rights reserved. 

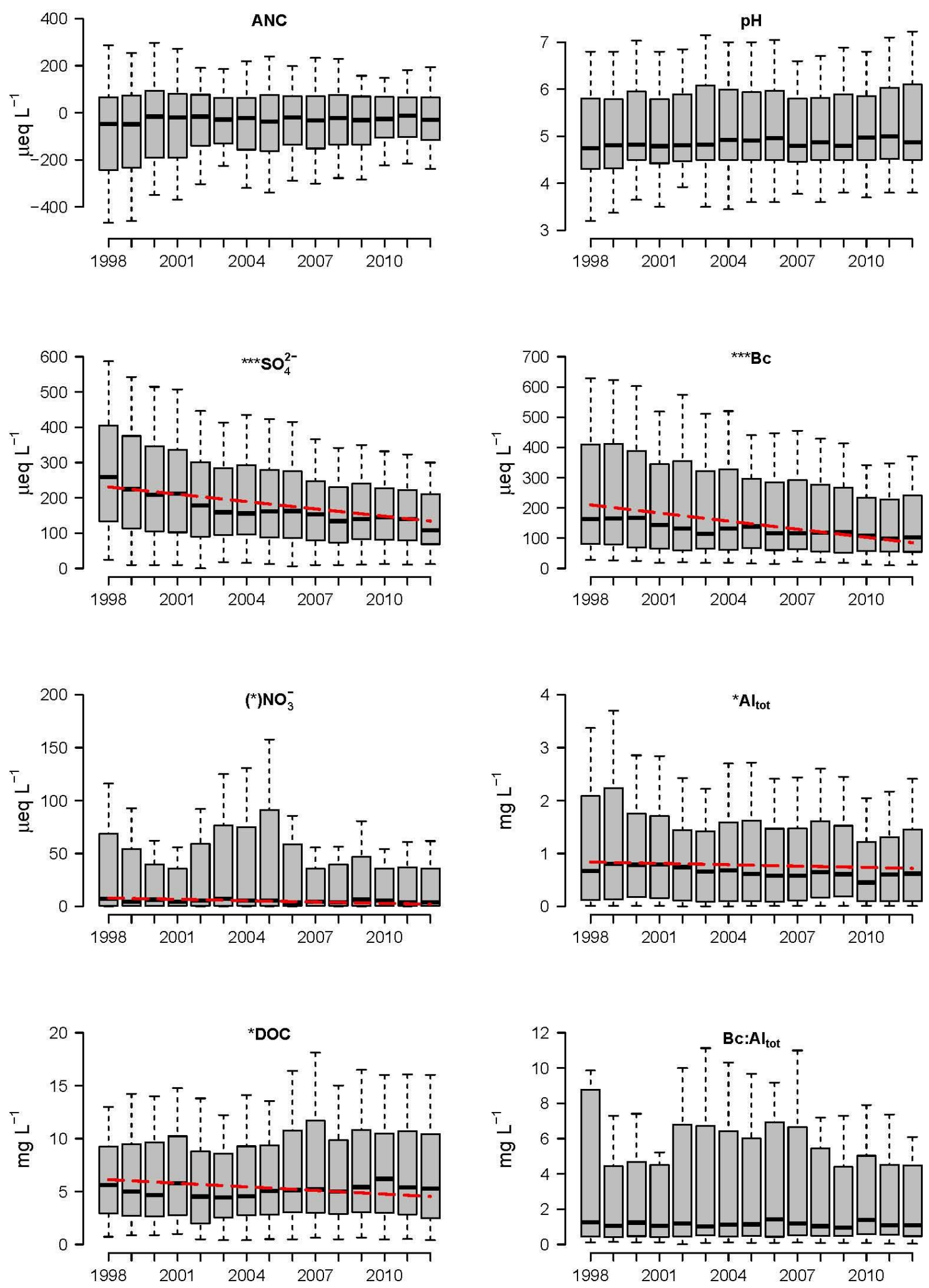

This article is protected by copyright. All rights reserved. 